Article

\title{
The Effects of Condensed Molasses Soluble on the Growth and Development of Rapeseed through Seed Germination, Hydroponics and Field Trials
}

\author{
Shuang $\mathrm{Li}^{1}{ }^{1}$, Xinghai Zhao ${ }^{1}$, Xiangsheng Ye ${ }^{1}$, Limei Zhang ${ }^{1}$, Lei Shi ${ }^{1,2}$, Fangsen $\mathrm{Xu}^{1,2}$ and \\ Guangda Ding 1,2,*(D) \\ 1 Microelement Research Center, Key Laboratory of Arable Land Conservation (Middle and Lower Reaches of \\ Yangtze River), College of Resources and Environment, Ministry of Agriculture and Rural Affairs, \\ Wuhan 430070, China; shuangli@webmail.hzau.edu.cn (S.L.); xinghaiz@webmail.hzau.edu.cn (X.Z.); \\ xiangshengye@mail.hzau.edu.cn (X.Y.); lmzhang@mail.hzau.edu.cn (L.Z.); leish@mail.hzau.edu.cn (L.S.); \\ fangsenxu@mail.hzau.edu.cn (F.X.) \\ 2 National Key Laboratory of Crop Genetic Improvement, Huazhong Agricultural University, \\ Wuhan 430070, China \\ * Correspondence: dgd@mail.hzau.edu.cn
}

Received: 14 June 2020; Accepted: 1 July 2020; Published: 2 July 2020

\begin{abstract}
Condensed molasses soluble (CMS) has been reported to be rich in mineral nutrients and organic matter. However, the potential of CMS as a new organic fertilizer for crops is poorly understood. In this study, we explored the effects of CMS on seed germination, plant growth and field production of Brassica napus through seed germination, hydroponics and field trials. The results demonstrated that a small amount of CMS $\left(0.05 \mathrm{~g} \mathrm{~L}^{-1}\right)$ on the basis of normal nutrient supply significantly increased plant biomass, root vigor and root development, and improved the superoxide dismutase (SOD) activity of shoot at the seedling growth stage. Nevertheless, a high concentration of CMS $\left(0.2 \mathrm{~g} \mathrm{~L}^{-1}\right)$ inhibited plant growth, root development, the activities of peroxidase (POD) and catalase (CAT), and elevated accumulation of malondialdehyde (MDA) in the shoot at the same stage. In the field, exogenous application of CMS as well as chemical fertilizers increased seed yield up to $20 \%$ compared with chemical fertilization only. Collectively, our results conclude that the appropriate amount of CMS could promote the growth and development of rapeseed at both seedling and mature stages. Hence, CMS may be used as a new potential organic fertilizer for crop production in the future.
\end{abstract}

Keywords: condensed molasses soluble; oilseed rape; seed germination; vegetative growth; seed yield; organic fertilizer

\section{Introduction}

Molasses is a primary by-product in the fermentation industry and can be used in the food industry such as in distilleries and sugar and yeast production [1,2]. However, these processes generate large amounts of wastewater. Molasses wastewater is characterized by a dark brown color and exhibits a high content of substances that are recalcitrant in nature, such as melanoidins, and its pigment is difficult to be degraded by microorganisms [3,4]. Moreover, the liquid waste of molasses is acidic, with a $\mathrm{pH}$ of 3.5 to 4.5 , and has a high concentration of organic materials and soluble, as well as high biological oxygen demand (BOD) and chemical oxygen demand (COD) [3,5]. Due to the presence of poorly biodegradable compounds, such as melanoidins, the treatment of molasses wastewater has become an arduous task. However, molasses wastewater is rich in mineral elements including nitrogen $(\mathrm{N})$, phosphorus $(\mathrm{P})$, potassium $(\mathrm{K})$, calcium $(\mathrm{Ca})$, sulfur $(\mathrm{S})$, micronutrients and organic matter [6]. 
Therefore, it is a challenge worldwide to use molasses wastewater legitimately, as it cannot be directly disposed of in water bodies for the potential of being detrimental to the environment.

After anaerobic treatment, molasses wastewater still contains considerable nutrients in terms of $\mathrm{N}, \mathrm{P}, \mathrm{K}$ and S, as well as micronutrients [7]. These nutrients are useful for crop production and could partly replace chemical fertilizers required by crops as well [8]. Studies showed that molasses waste has long been used to irrigate sugarcane directly and to generate remarkable economic benefits $[6,9,10]$. For example, irrigation with distillery effluent could directly increase crop yields, dry matter production, total chlorophyll content and leaf area [6,11]. Condensed Molasses Soluble (CMS) is believed to have an improved nutrient composition compared with that of standard sugar mill molasses [10]. CMS is used as a compound fertilizer to economic crops [10,12]. It is reported that CMS can increase the availability of N, P, K and organic matter in soil compared to chemical fertilizers, and finally increase crop yield. For example, the amendment of CMS in sugarcane increased the emergence rate, tillering rate, chlorophyll contents and yield compared with conventional fertilization, and resulted in improved physicochemical properties of soil [13]. The direct application of CMS promoted the growth of sugarcane during the seedling stage and the net photosynthetic rate without showing any harmful effects. In addition, irrigation of sugarcane with CMS increased the activities of $\mathrm{N}$ metabolism, polyphenol oxidase (PPO), peroxidase (POD), and catalase (CAT) as well as the contents of chlorophyll, total $\mathrm{N}$ and water-soluble protein [14-16]. These results indicate that the application of CMS is beneficial for crop production as well as for the physical improvement in soil structure and an increase in the biological activity of beneficial micro-organisms [8-10].

Reactive oxygen species (ROS) are considered to be unavoidable by-products of aerobic metabolism and play a multitude of signaling roles in different organisms [17]. Generally, ROS is composed of both free radical and non-radial (molecular) forms. Various abiotic stresses, such as Al toxicity or salt stress may result in the overproduction of ROS in plants, which could disrupt the homeostasis and normal metabolism in cells by oxidizing lipids, proteins and nucleic acids, and eventually cause damage to plant cells. However, higher plants have developed pathways and mechanisms to protect themselves from ROS toxicity [18]. Plants can eliminate excessive ROS by enzymatic antioxidant systems including a variety of scavengers, such as superoxide dismutase (SOD), CAT and dehydroascorbate reductase (MDHAR), and non-enzymatic low molecular metabolites, such as ascorbic acid (ASH), glutathione (GSH) and non-protein amino acids [18,19]. Among them, SOD decomposes $\mathrm{O}_{2}$ into $\mathrm{O}_{2}$ and $\mathrm{H}_{2} \mathrm{O}_{2}$, and further oxidizes $\mathrm{H}_{2} \mathrm{O}_{2}$ into $\mathrm{O}_{2}$ and $\mathrm{H}_{2} \mathrm{O}$ by CAT and POD. Excessive ROS production leads to oxidative damage and lipid peroxidation of membranes in the form of malondialdehyde (MDA), which is the final product and an important hallmark for monitoring programmed cell death (PCD) [20]. It has been reported that large-scale application of organic fertilizer could induce the accumulation of ROS, and thus inhibit the growth and development of crops [21]. For example, the application of organic fertilizer could significantly increase the activities of SOD, POD and CAT, and decrease MDA accumulation in Chinese cabbage [22]. In addition, the application of molasses wastewater plays some roles in increasing the rate of development and tillering of sugarcane seedlings, by regulating the antioxidant enzyme systems to reduced ROS damages [14,15].

Molasses wastewater can reduce the cost of fertilization, and promote the recycling of resources, which has far-reaching significance in agriculture. In the past few decades, most of the studies focused on the direct irrigation of molasses wastewater mainly in sugarcane production, whereas few studies have discussed how molasses wastewater affects the growth of oil crops such as rapeseed. Oilseed rape (Brassica napus L.) is an important oil crop cultivated worldwide. It is commonly used in animal feed or as an oil source for humans. Thus, it is necessary to study the feasibility of molasses wastes as a new type of organic fertilizer for B. napus as well as the application approaches. Keeping this in view, the aims of this study were to investigate the effects of CMS on the growth, development, seed yield and quality of B. napus, and to explore the feasibility and effective application of CMS in rapeseed production through seed germination, hydroponics and field experiments. 


\section{Materials and Methods}

\subsection{Plant Materials and Germination Trials}

A rapeseed cultivar named "Zhongshuang 11" was used in this study. The nutrient concentrations of the CMS are shown in Table 1. The germination trials were conducted by using five concentration gradients of CMS including 0.02, 0.05, 0.10, 0.15 and $0.20 \mathrm{~g} \mathrm{~L}^{-1}$. The intact and uniform seeds were soaked in different concentrations of CMS for 1-2 $\mathrm{d}$ and then sown in a pot covered by gauze. After culturing in a controlled growth chamber for $5 \mathrm{~d}$ in the dark, seeds germination, seedling rate, root length, plant height and plant biomass were measured and recorded.

Table 1. The concentrations of 15 mineral elements in Condensed Molasses Soluble (CMS).

\begin{tabular}{cccc}
\hline Component & Concentration (\%) & Component & Concentration $\mathbf{( m g ~ k g}^{-\mathbf{1}} \mathbf{)}$ \\
\hline $\mathrm{N}$ & 2.38 & $\mathrm{Fe}$ & 54.32 \\
$\mathrm{P}$ & 0.5 & $\mathrm{Zn}$ & 340.12 \\
$\mathrm{~K}$ & 5.95 & $\mathrm{Mn}$ & 50.64 \\
$\mathrm{~S}$ & 0.59 & $\mathrm{Cu}$ & 5.1 \\
$\mathrm{Ca}$ & 0.51 & $\mathrm{Mo}$ & 0.07 \\
$\mathrm{Mg}$ & 0.7 & $\mathrm{~B}$ & 0.06 \\
$\mathrm{Cl}$ & 6.73 & $\mathrm{Ni}$ & 0.02 \\
$\mathrm{Na}$ & 1.93 & & \\
\hline
\end{tabular}

\subsection{Hydroponic Experiments}

The modified Hoagland's nutrient solution ( $\mathrm{pH}$ 5.8) was used for the hydroponic culture experiment with different concentrations of CMS in this study [23]. The solution contained $\mathrm{Ca}\left(\mathrm{NO}_{3}\right)_{2}$ $5.0 \mathrm{mM}, \mathrm{KNO}_{3} 5.0 \mathrm{mM}, \mathrm{KH}_{2} \mathrm{PO}_{4} 1.0 \mathrm{mM}, \mathrm{MgSO}_{4} 2.0 \mathrm{mM}, \mathrm{H}_{3} \mathrm{BO}_{3} 46.0 \mu \mathrm{M}, \mathrm{MnCl}_{2} 9.0 \mu \mathrm{M}, \mathrm{CuCl}_{2} 0.3 \mu \mathrm{M}$, $\mathrm{ZnCl}_{2} 0.8 \mu \mathrm{M}, \mathrm{Na}_{2} \mathrm{MoO}_{4} 0.32 \mu \mathrm{M}$ and EDTA-Fe $50.0 \mu \mathrm{M}$. Firstly, the seeds were soaked into distilled water overnight, then sown on gauze evenly. After 3-5d, the uniform seedlings were transplanted to plastic pots with a nutrient solution in day/night temperature cycle of $24 / 18{ }^{\circ} \mathrm{C}, 65-85 \%$ relative humidity with a $14 / 10-\mathrm{h}$ photoperiod $\left(300-320 \mu \mathrm{M}\right.$ photons $\left.\mathrm{m}^{-2} \mathrm{~s}^{-1}\right)$. Then, 0.05 and $0.2 \mathrm{~g} \mathrm{~L}^{-1} \mathrm{CMS}$ were added to the solution. The nutrient solution was refreshed every three days. After 20 days' growth in two concentrations of CMS, the shoot and root of the plants were harvested for further analysis.

\subsection{Field Trials}

The field test was carried out at Huazhong Agricultural University, Wuhan, China. The experimental field soil was yellowish-brown clay loam with $\mathrm{pH} 5.84$ (1:5 soil:water suspension), organic matter $12.99 \mathrm{~g} \mathrm{~kg}^{-1}$, total $\mathrm{N} 0.7 \mathrm{~g} \mathrm{~kg}^{-1}$, exchangeable $\mathrm{K} 141.14 \mathrm{mg} \mathrm{kg}^{-1}$ and Olsen-P $9.79 \mathrm{mg} \mathrm{kg} \mathrm{g}^{-1}$ in the $0-20 \mathrm{~cm}$ soil profile and sampled before fertilization. The local farming mode is rapeseed-rice cultivation rotation. Field management was performed following the local methods, such as spraying $100 \mathrm{~mL} \mathrm{ha}^{-1} 33 \%$ Pendimet for weeding. In this study, a total of 10 treatments were conducted and are shown in Table 2. Generally, T1-T4 treatments had no chemical fertilizers, while normal fertilization was used in T5-T10. Different amounts of CMS were applied in T2, T3, T4, T6 and T7 before sowing. For T8-T9 treatments, $200 \mathrm{~g} \mathrm{~m}^{-2} \mathrm{CMS}$ was applied at different growth stages. The amount of chemical fertilizers applied for each treatment was calculated according to the following rates: $\mathrm{N} 180 \mathrm{~kg} \mathrm{ha}^{-1}$; $\mathrm{P}_{2} \mathrm{O}_{5} 90 \mathrm{~kg} \mathrm{ha}^{-1} ; \mathrm{K}_{2} \mathrm{O} 120 \mathrm{~kg} \mathrm{ha}^{-1}$; borax $15 \mathrm{~kg} \mathrm{ha}^{-1}$. $\mathrm{K}$ as potassium chloride and $\mathrm{P}$ as ordinary superphosphate were applied before sowing, and $\mathrm{N}$ as urea was applied into splits as $108 \mathrm{~kg}$ before sowing, $36 \mathrm{~kg}$ at the seedling stage and $36 \mathrm{~kg}$ at the bolting stage. The seeds of "Zhongshuang 11" were sown at the end of September, and the plants were harvested at the beginning of the following May. Planting was conducted using a randomized complete block arrangement with four replicates. The individual plot area was $3.6 \mathrm{~m}^{2}$, with a length of $2.0 \mathrm{~m}$ and width $1.8 \mathrm{~m}$. The seeds were sown manually, and the sowing depth was $0.5-1.0 \mathrm{~cm}$. Seeds were dibbled and row spacing was $0.25 \mathrm{~m}$, 
$0.2 \mathrm{~m}$ per hole and two-three seeds per hole. Samples were taken at the maturity stage to determine the biomass, seed yield, yield-related traits and nutrient contents. The soils were sampled after harvest, and organic matter and nutrient contents were examined.

Table 2. Nutrient application amount for the field trial of Brassica napus during the growth season.

\begin{tabular}{cccc}
\hline Treatments & CMS $\left(\mathbf{g ~ m}^{\mathbf{2}}\right)$ & Normal Chemical Fertilizer & CMS Application Period \\
\hline T1 & - & - & - \\
T2 & 50 & - & Before planting \\
T3 & 200 & - & Before planting \\
T4 & 500 & - & Before planting \\
T5 & - & + & - \\
T6 & 50 & + & Before planting \\
T7 & 200 & + & Before planting \\
T8 & 200 & + & Seedling stage \\
T9 & 200 & + & Bolting stage \\
T10 & 200 & + & Flowering stage \\
\hline
\end{tabular}

\subsection{Determination of Plant Growth Parameters}

After harvesting, the fresh weight of the above-ground parts of all samples was dried to constant weight and weighed. Six traits at the maturing stage including plant height $(\mathrm{PH})$, first primary branch height (FBH), branch number (BN), pod number per plant (PN), seed number per pod (SNP), seed weight (SW) and seed yield (SY) were measured and recorded as described previously [24]. In brief, SY was recorded as the average seed dry weight of each individual. SW was measured based on 1000 fully developed seeds of each plant. SNP was counted as the average number of well-filled seeds from 100 well-developed pods, which were sampled from the primary branch in the middle of the harvested individuals. PN was the number of well-developed pods on each plant. BN was counted as the number of primary branches arising from the main branch. FBH was measured from ground level to the base of the lowest primary branch. $\mathrm{PH}$ was measured from the base of the stem to the tip of the main shoot of each plant.

The root traits at the seedling stage were scanned with Epson Perfection V700 and the images were analyzed by WinRHIZO Pro (Regent Instruments, Montreal, QC, Canada) to determine root morphological parameters, including primary root length, lateral root number, lateral root length, root surface area, root volume, and root diameter.

For the analysis of the chlorophyll contents at the seedling stage, fresh leaves $(\sim 0.1 \mathrm{~g})$ were sampled and taken into $2 \mathrm{~mL}$ centrifuge tube with $2 \mathrm{~mL} 80 \%$ acetone and $10 \mathrm{mg} \mathrm{CaCO}$, and then extracted at $4{ }^{\circ} \mathrm{C}$ for $12 \mathrm{~h}$ in the dark. The content of chlorophyll was measured at wavelengths 645 and 663 , using $80 \%$ acetone as a blank. The chlorophyll contents were corrected and calculated according to the formula reported previously [25]. The details are as follows:

$$
\begin{aligned}
& \text { Chlorophyll } \mathrm{a}=\left(12.72 \mathrm{~A}_{663}-2.69 \mathrm{~A}_{645}\right) \times \mathrm{V} / \mathrm{W} \times 1000 \\
& \text { Chlorophyll } \mathrm{b}=\left(22.88 \mathrm{~A}_{645}-4.67 \mathrm{~A}_{663}\right) \times \mathrm{V} / \mathrm{W} \times 1000 .
\end{aligned}
$$

\subsection{Determination of Root Vitality and Enzyme Activities in Plants}

The content of MDA was measured according to the method reported previously [26]. Briefly, $1.0 \mathrm{~g}$ of fresh root and shoot were homogenized by mortar in $10 \mathrm{~mL}$ of $10 \%$ trichloroacetic acid (TCA) and then centrifuged at 12,000 rpm for $15 \mathrm{~min}$. After that, the supernatant was collected and incubated in a water bath at $98^{\circ} \mathrm{C}$ for $20 \mathrm{~min}$. After cooling and centrifugation, the supernatants were used to determine the absorbance at wavelengths of $450 \mathrm{~nm}, 532 \mathrm{~nm}$ and $600 \mathrm{~nm}$, respectively. The MDA contents were calculated according to the formula: $\mathrm{MDA}=6.45\left(\mathrm{D}_{532}-\mathrm{D}_{600}\right)-0.56 \mathrm{D}_{450}$. 
For determination of the antioxidant enzyme activities, $0.5 \mathrm{~g}$ of fresh samples (root and shoot) were homogenized with pre-cooled $50 \mathrm{mM}$ phosphate buffer ( $\mathrm{pH} 7.0)$ on ice and centrifuged at $4{ }^{\circ} \mathrm{C}$ $(13,000 \times g)$ for $20 \mathrm{~min}$. The supernatant was used to measure the activity of SOD, CAT, POD and the contents of soluble protein. The SOD activity was measured by the method reported by Beauchamp [27]. The activity of CAT was detected by the decrease in absorbance according to Aebi [28]. The POD activity was assayed over $3 \mathrm{~min}$ at $470 \mathrm{~nm}$ by spectrophotometer and expressed as $\mathrm{U} \mathrm{g}^{-1} \mathrm{~min}^{-1}$ [29]. The content of soluble protein was quantified according to the method described by Hachiya [30].

The modified triphenyltetrazolium chloride (TTC) method was used for the analysis of root vigor according to Clemensson-Lindell [31]. In brief, $0.25 \mathrm{~g}$ sample was taken into a conical flask, and $5 \mathrm{~mL}$ of $0.5 \%$ TTC and $0.1 \mathrm{M}$ phosphate buffer ( $\mathrm{pH} 7.5$ ) was added, then mixed completely and incubated at $37^{\circ} \mathrm{C}$ for $1 \mathrm{~h}$. After incubation, $2 \mathrm{~mL}$ of $1 \mathrm{M} \mathrm{H}_{2} \mathrm{SO}_{4}$ was used to immediately stop the reaction. Tips showing red color indicate active dehydrogenase.

\subsection{Determination of Nutrient Contents in Plants}

The harvested samples were digested with $\mathrm{H}_{2} \mathrm{SO}_{4}-\mathrm{H}_{2} \mathrm{O}_{2}$ as described previously by Thomas [32]. Briefly, after the samples were dried to constant weight, about $0.1 \mathrm{~g}$ sample was taken into the digestive tube $(50 \mathrm{~mL})$. Then, $5 \mathrm{~mL}$ of $98 \% \mathrm{H}_{2} \mathrm{SO}_{4}$ was added into the tube and kept overnight. The digestion tube was put in the heating block and digested at $250{ }^{\circ} \mathrm{C}$ for $2 \mathrm{~h}$ with $5-10$ drops of $\mathrm{H}_{2} \mathrm{O}_{2}$. The $\mathrm{N}$ and $\mathrm{P}$ concentrations in the digested solution were analyzed using a flow injection analysis instrument (FIAstar 5000 analyzer; FOSS, Hilleroed, Denmark). The K concentration in the digestion solution was measured using a flame photometer (M-410, Cole-Parmer, Chicago, IL, USA). Nutrient accumulation was calculated by multiplying the mineral concentration of each sample by the dry weight. Nutrient use efficiency was the ratio of dry weight and nutrient accumulation. Nutrient use index was defined as the ratio of dry weight and nutrient concentration.

\subsection{Measurement of Nutrient Contents in Soils}

After harvesting plants, soil samples were collected from the $0-20 \mathrm{~cm}$ depth at five randomly selected locations and mixed as a composite sample at every experimental site. After the soils were sampled, they were air-dried at room temperature and crushed to pass through a 1-mm sieve for chemical analysis. The organic matter was analyzed according to the dichromate oxidation method, total $\mathrm{N}$ was detected following the Kjeldahl acid-digestion method. The available $\mathrm{P}$ and available $\mathrm{K}$ were measured according to the methods described by Sparks [33].

\subsection{Statistical Analysis}

All data were analyzed and processed by Microsoft Office Excel 2016 (Microsoft, Redmond, WA, USA) and SPSS 22.0 software (IBM, Armonk, NY, USA). Graphs were generated by GraphPad Prism 7 (GraphPad Software, San Diego, CA, USA). Duncan's test was used for all significant analysis. The letters indicate the significance at $p<0.05$ confidence level. Error bars represent standard deviation (SD) values.

\section{Results}

\subsection{Effects of CMS on Rapeseed Germination and Seedling Growth}

To investigate the effects of CMS on the seed germination of rapeseed, seeds were treated with five different concentrations of CMS, using double distilled water $\left(\mathrm{ddH}_{2} \mathrm{O}\right)$ as a control. Then, seed germination rate was recorded during the first, second and third days after sowing. The results showed significant differences under different CMS treatments (Figure 1). The germination rate under six treatments were $63 \%, 45 \%, 40 \%, 55 \%, 33 \%$ and $58 \%$, respectively, during the first day, while it was the highest under $0.2 \mathrm{~g} \mathrm{~L}^{-1} \mathrm{CMS}$ condition compared to other treatments. However, the differences between the six treatments were smaller with time. On the third day, the germination rate reached more 
than $90 \%$ under all the treatments (Figure 1B). No significant effects among different concentrations of CMS were detected in rapeseed germination on the third day. To further illustrate the effects of CMS on the growth of rapeseed seedlings, we analyzed the fresh weight, root length and elongation (Figure 1C,D). The results showed that the root length was increased first and then decreased with the increase of CMS concentration. The root length under $0.05 \mathrm{~g} \mathrm{~L}^{-1} \mathrm{CMS}$ was about $60 \%$ longer than that under pure water and reached the highest. We found that the root growth rate showed significant differences between $\mathrm{ddH}_{2} \mathrm{O}$ and other CMS treatments as well, except under $0.2 \mathrm{~g} \mathrm{~L}^{-1} \mathrm{CMS}$, indicating that CMS can promote the growth of rapeseed root at a low concentration. By analyzing the total biomass (fresh weight) of rapeseed seedlings, we found that the application of CMS did not increase the biomass. Instead, a high concentration of CMS $\left(0.2 \mathrm{~g} \mathrm{~L}^{-1}\right)$ inhibited the growth of rapeseed at the early stage (Figure 1C).

A

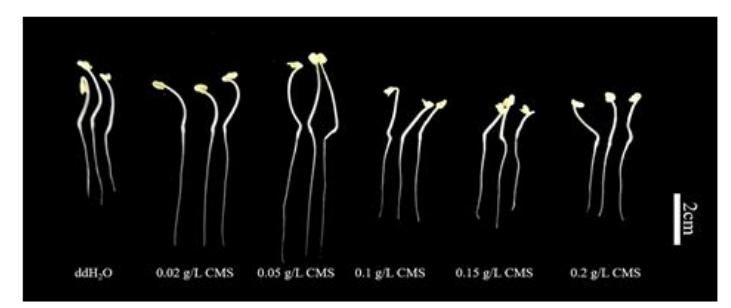

C

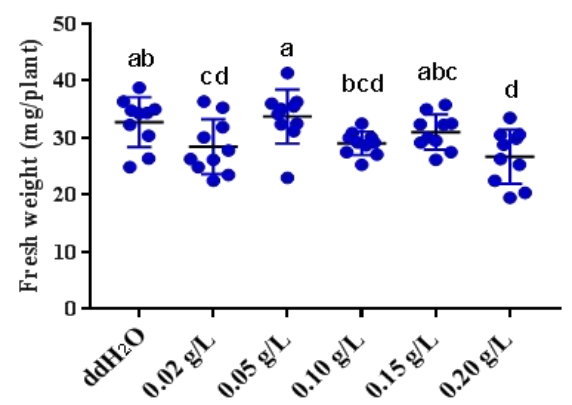

B
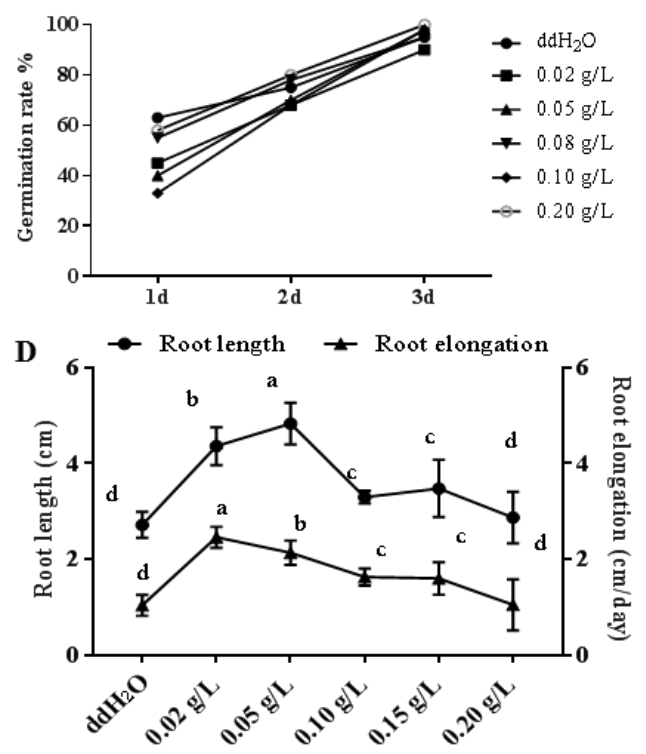

Figure 1. Effects of different concentrations of CMS on Brassica napus seedling growth (A), germination (B), fresh weight (C) and root growth (D). 1d, 2d, 3d indicate 1, 2, 3 days after sowing. Different letters indicate the significant differences at $p<0.05$ by Duncan's test. $\mathrm{N}=10$.

\subsection{Effects of CMS on Biomass, Root Vigor and Root Morphology in Rapeseed}

To further analyze the impact of CMS on rapeseed growth and the regulatory mechanism, we investigated the performance of rapeseed grown under normal nutrient solution and two concentrations of CMS ( 0.05 and $\left.0.2 \mathrm{~g} \mathrm{~L}^{-1}\right)$ in addition to nutrients in the solutions at the seedling stage. The results showed that the addition of $0.05 \mathrm{~g} \mathrm{~L}^{-1} \mathrm{CMS}$ in normal nutrient solution significantly promoted the growth of rapeseed compared with the control treatment. However, high concentrations of CMS $\left(0.20 \mathrm{~g} \mathrm{~L}^{-1}\right)$ in the solution significantly inhibited the growth (Figure $\left.2 \mathrm{~A}, \mathrm{~B}\right)$. Subsequently, we analyzed the root vitality of rapeseed under three conditions by TTC [31]. The results showed a deeper color in the solution with $0.20 \mathrm{~g} \mathrm{~L}^{-1} \mathrm{CMS}$ than in the other two treatments, indicating higher root vigor in the CMS conditions than in the control condition (Figure 2C,D). These results suggested that the addition of CMS in the growth environment increased the root vigor of rapeseed. The higher concentrations of CMS in the environment, the stronger the root vigor will be. 
A

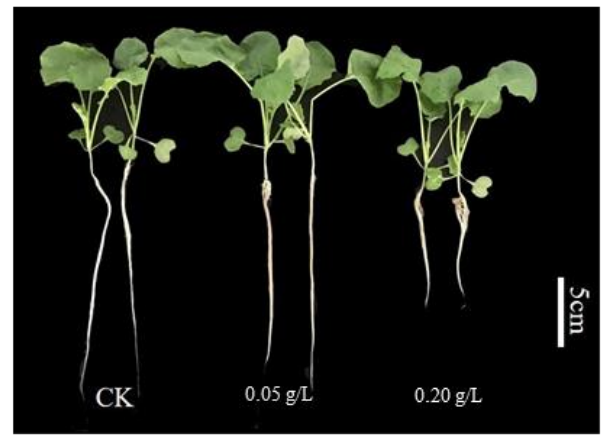

C

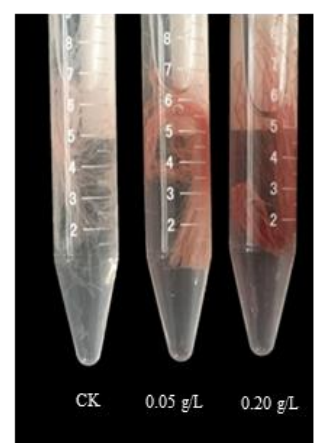

B

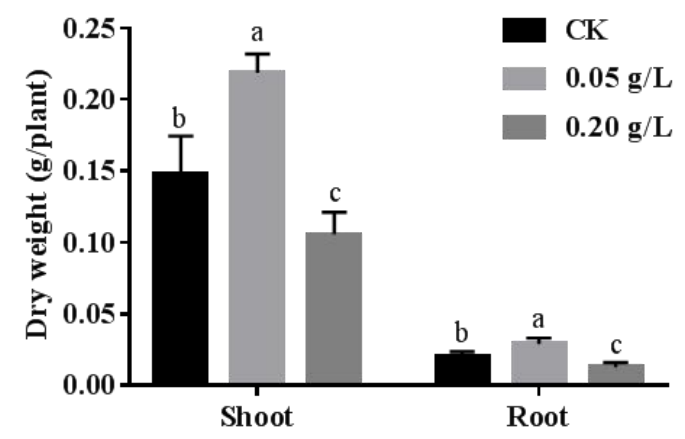

D

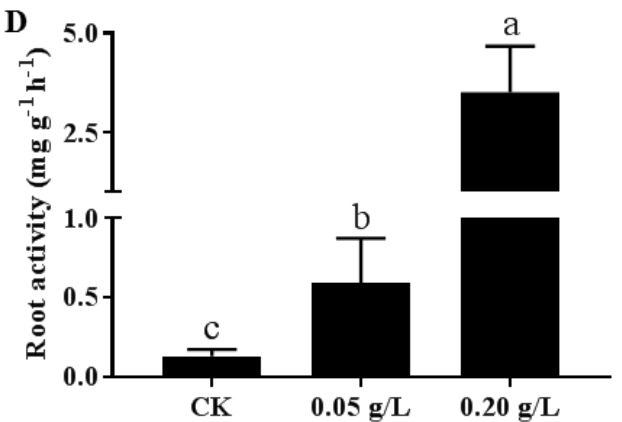

Figure 2. Effects of different concentrations of CMS on rapeseed seedling growth (A), biomass (B) and root vitality (C and D). Control (CK) is a full-strength Hoagland's solution. Two concentrations (0.05 and $0.2 \mathrm{~g} \mathrm{~L}^{-1}$ ) of CMS were added to the Hoagland's solution. Different letters indicate the significant differences at $p<0.05$ by Duncan's test. Data are means \pm SD with four biological replicates.

In addition to the plant growth and root vigor, we analyzed root architecture of rapeseed seedlings by WinRHIZO Pro, including total root length, primary root length, total root projected area, total root volume, total root surface area, average diameter, number of root tips, number of crossings and number of forks under different concentrations of CMS. We found that the total root volume, total root length, total root surface area and total projected area of rapeseed significantly increased under 0.05 CMS but decreased under $0.20 \mathrm{~g} \mathrm{~L}^{-1}$ CMS compared to that under control condition (Figure 3). However, the primary root length showed a significant decrease with the increase of CMS, while the root average diameter showed opposite results, indicating that exogenous CMS can inhibit the elongation of primary root but make root thicker than only mineral nutrients treatment. Moreover, there were no differences for the number of root tips, crossings and root forks under $0.05 \mathrm{~g} \mathrm{~L}^{-1} \mathrm{CMS}$ treatment compared to that under control condition, but a significant decrease was observed for these traits under $0.20 \mathrm{~g} \mathrm{~L}^{-1} \mathrm{CMS}$ compared to that under the other two treatments (Figure 3G).

\subsection{Effects of CMS on Chlorophyll Content in Rapeseed at the Seedling Growth Stage}

To further explore whether CMS affects photosynthesis in rapeseed leaves, we determined the contents of chlorophyll a and chlorophyll $\mathrm{b}$ in the leaves under three treatments. The results showed that CMS had no significant effects on the content of chlorophyll a and chlorophyll $b$ in fully expanded leaves, but the new leaves showed a significant decline on the chlorophyll content compared with that under control condition (Figure 4). Thus, the exogenous application of CMS might reduce the content of chlorophyll in the newly grown leaves and inhibited the photosynthesis of rapeseed. 
$\mathbf{A}$

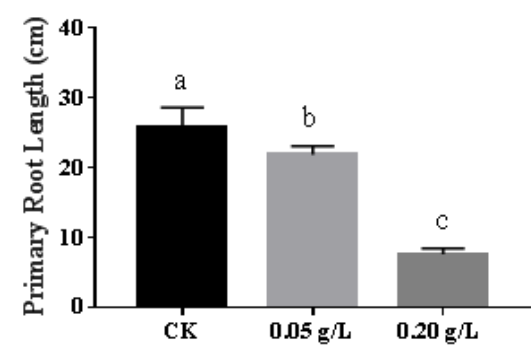

C

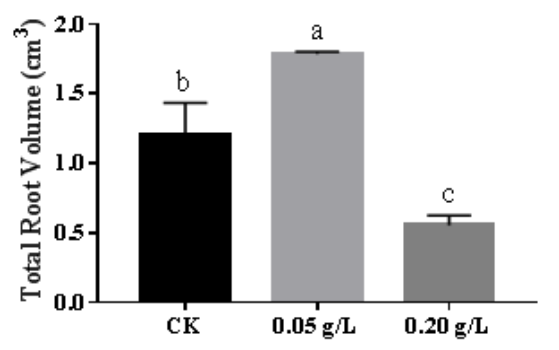

$\mathbf{E}$

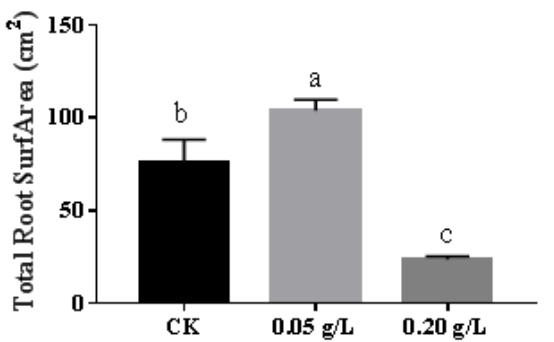

G

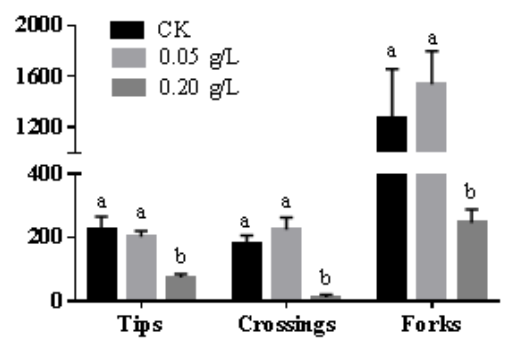

B
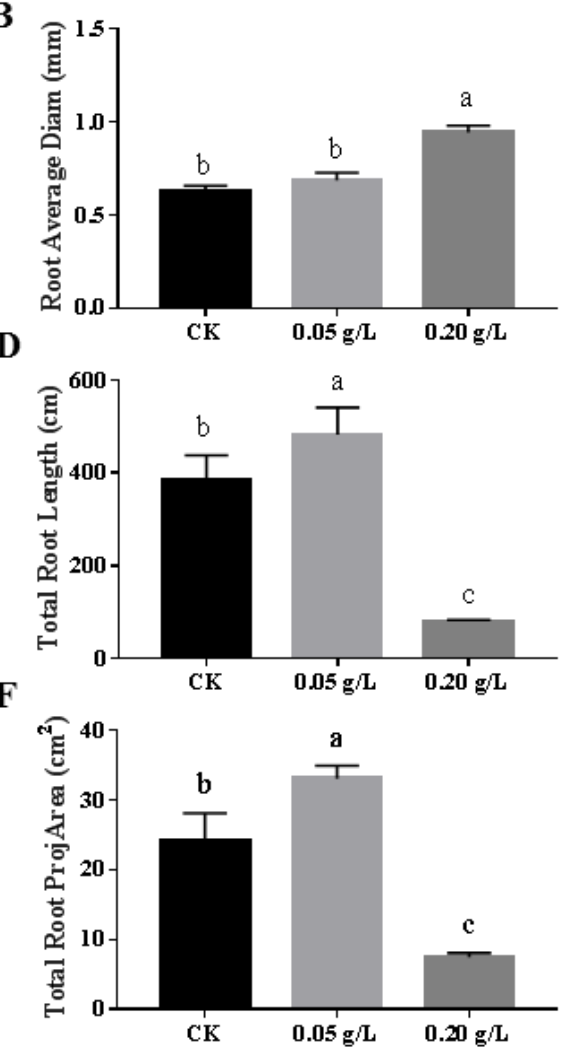

$\mathbf{H}$

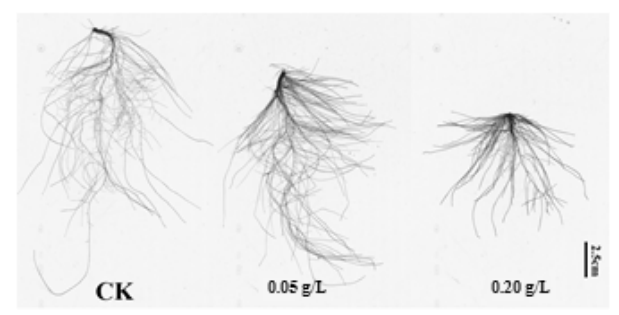

Figure 3. Effects of different concentrations of CMS on the root growth of Brassica napus. CK is a full-strength Hoagland's solution. Two concentrations ( 0.05 and $\left.0.20 \mathrm{~g} \mathrm{~L}^{-1}\right)$ of CMS were added to the Hoagland's solution. (A) Primary root length; (B) Root average diameter; (C) Total root volume; (D) Total root length; (E) Total root surface area; (F) Total root projected area; (G) Root tips, forks and crossings; (H) Root architecture. Different letters indicate the significant differences at $p<0.05$ by Duncan's test. Data are means \pm SD with four biological replicates.

\subsection{Effects of CMS on the Regulation of Nutrient Absorption, Accumulation, and Utilization in Rapeseed}

CMS contains a large number of mineral nutrients (Table 1). To analyze the effect of CMS on the nutrient uptake and utilization of rapeseed during the seedling stage, we measured the concentrations of $\mathrm{N}, \mathrm{P}$ and $\mathrm{K}$ in shoot and root under three treatments, and calculated the accumulation and nutrient use efficiency of the three elements. We found that there were no significant differences in the contents of N, P and K in shoot among the three treatments, but the exogenous application of CMS increased the concentrations of $\mathrm{P}$ and $\mathrm{N}$ in root compared to that under normal nutrient level (Figure 5). By comparing the accumulation of nutrients in shoot and root of rapeseed under CMS environment with that under normal nutrient condition, we found that the contents of $\mathrm{N}, \mathrm{P}$ and $\mathrm{K}$ showed significant increase under $0.05 \mathrm{~g} \mathrm{~L}^{-1} \mathrm{CMS}$ but significant decline under $0.20 \mathrm{~g} \mathrm{~L}^{-1} \mathrm{CMS}$ in the shoot of rapeseed. While in the root, exogenous application of $0.05 \mathrm{~g} \mathrm{~L}^{-1} \mathrm{CMS}$ increased the nutrient accumulation as well. These results indicated that exogenous CMS can promote the uptake and accumulation of $\mathrm{P}$ and $\mathrm{N}$ in rapeseed. 

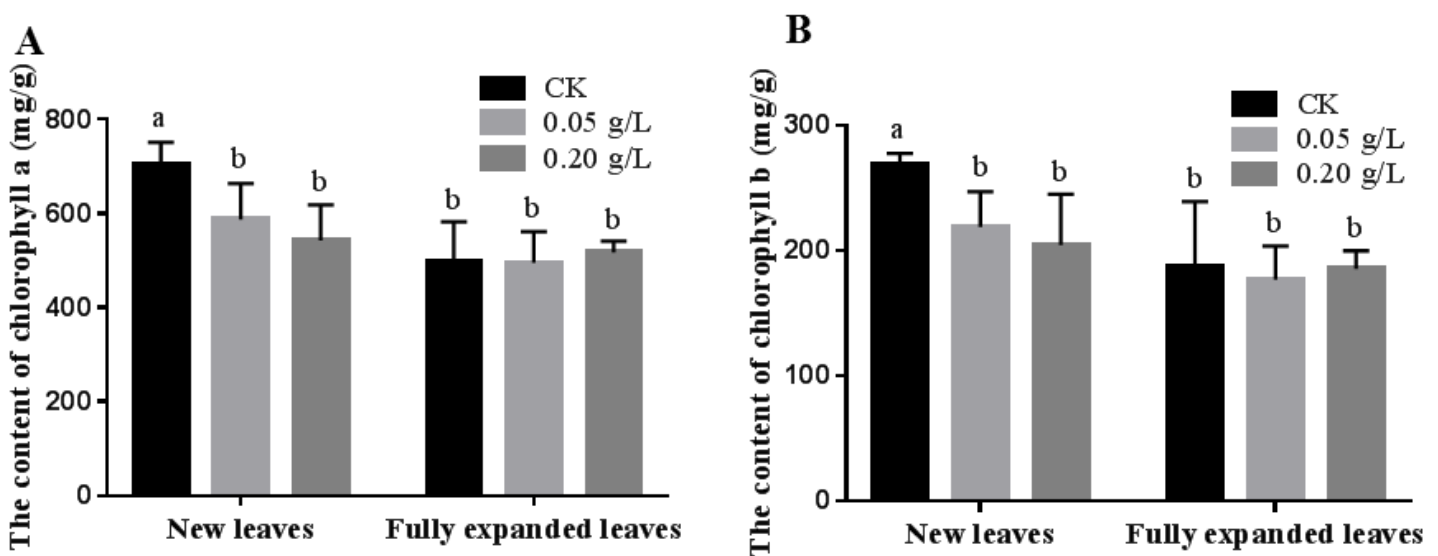

Figure 4. The concentrations of Chlorophyll a (A) and b (B) in leaves of Brassica napus seedlings under different CMS treatments. CK is a full-strength Hoagland's solution. Two concentrations $(0.05$ and $0.20 \mathrm{~g} \mathrm{~L}^{-1}$ ) of CMS were added to the Hoagland's solution. Different letters indicate the significant differences at $p<0.05$ by Duncan's test. Data are means \pm SD with four biological replicates.

A

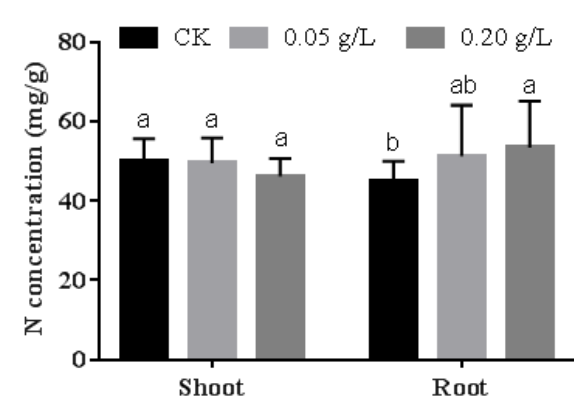

B

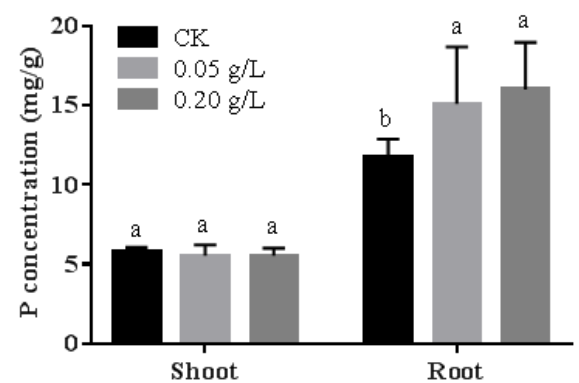

C

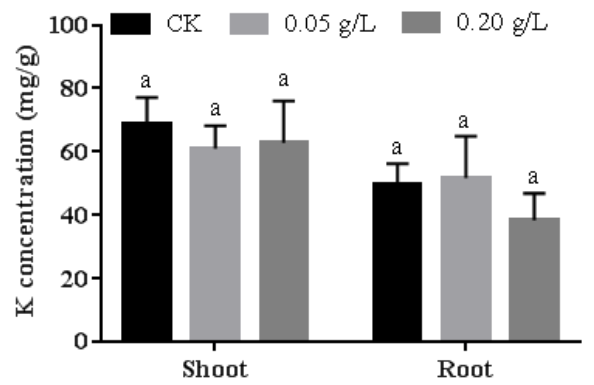

D

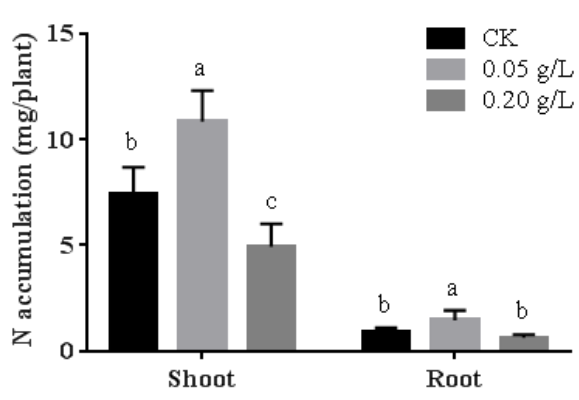

E

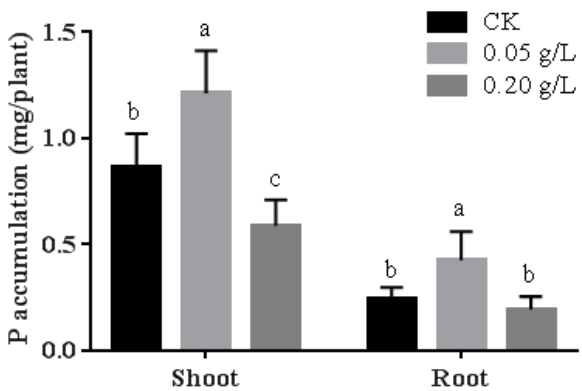

F

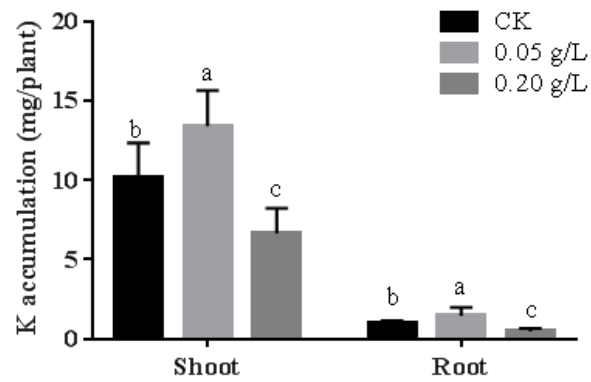

Figure 5. The concentration and content of nitrogen $(\mathrm{N})$, phosphorus $(\mathrm{P})$ and potassium $(\mathrm{K})$ in shoot and root of Brassica napus under different CMS treatments. CK is a full-strength Hoagland's solution. Two concentrations $\left(0.05\right.$ and $\left.0.20 \mathrm{~g} \mathrm{~L}^{-1}\right)$ of CMS were added to the Hoagland's solution. (A) $\mathrm{N}$ concentration; (B) P accumulation; (C) K concentration; (D) N accumulation; (E) P accumulation; (F) K accumulation. Different letters indicate the significant differences at $p<0.05$ by Duncan's test. $\mathrm{N}=6$. 
We further analyzed the utilization efficiency and nutrient index in rapeseed and found that there was no significant difference in both shoot and root of rapeseed (Figure 6). However, for the utilization index of the shoot and root, we found that the low concentration of CMS significantly increased the utilization index of N, P and $\mathrm{K}$ in the shoot and root of rapeseed compared with the control condition. However, high CMS concentration reduced the nutrient use efficiency (Figure 6). These results indicated that low concentrations of CMS increased nutrient utilization index and promoted the growth and development of rapeseed without affecting the nutrient utilization rate, but there were no positive effects or even negative effects under the high concentration of CMS.

A

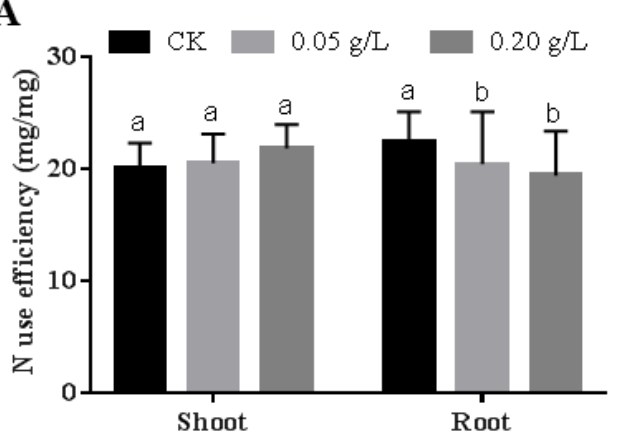

B

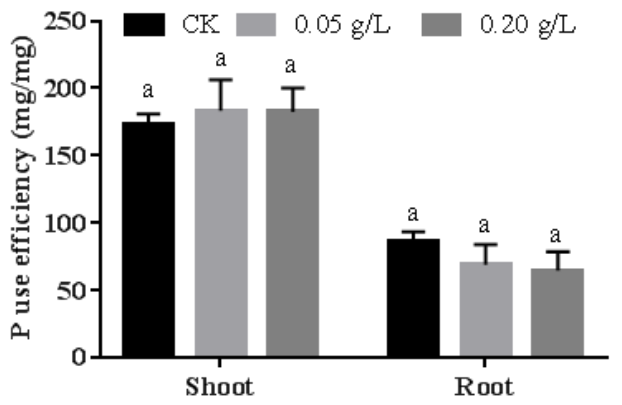

C

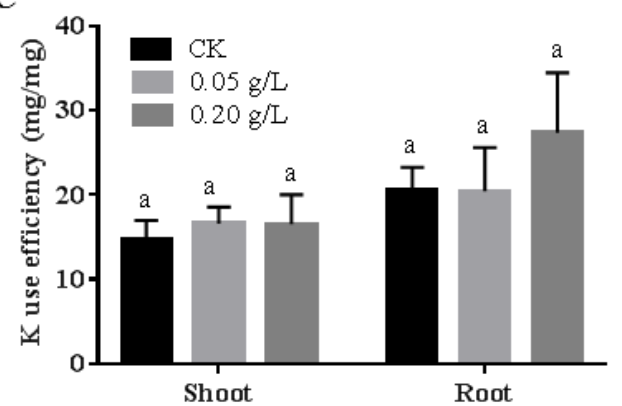

D

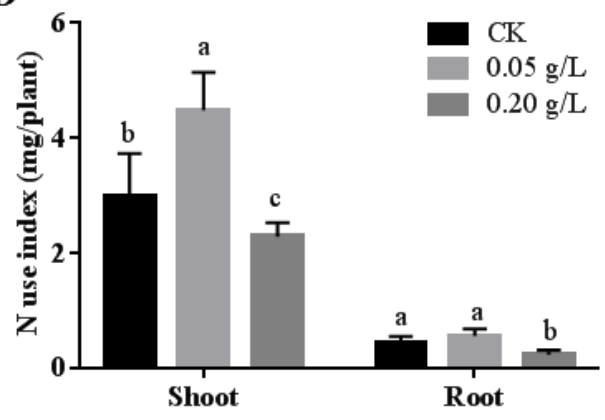

$\mathbf{E}$

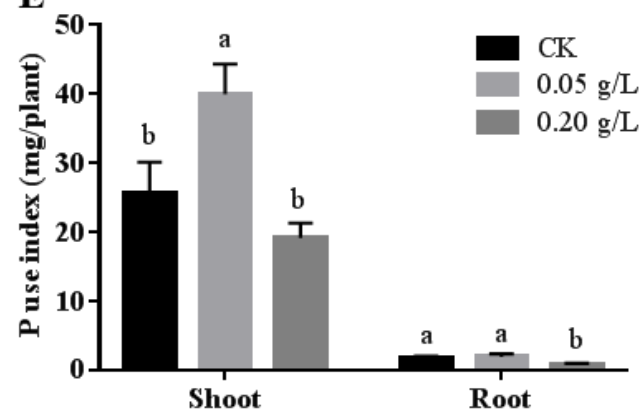

F

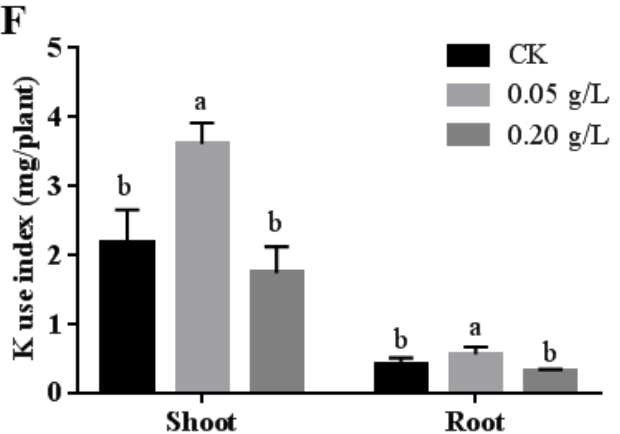

Figure 6. The use efficiency and use index of nitrogen $(\mathrm{N})$, phosphorus $(\mathrm{P})$ and potassium $(\mathrm{K})$ in Brassica napus under different CMS treatments. CK is a full-strength Hoagland's solution. Two concentrations ( 0.05 and $0.20 \mathrm{~g} \mathrm{~L}^{-1}$ ) of CMS were added to the Hoagland's solution. (A) $\mathrm{N}$ use efficiency; (B) P use efficiency; (C) K use efficiency; (D) N use index; (E) P use index; (F) K use efficiency. Different letters indicate the significant differences at $p<0.05$ by Duncan's test. Data are means \pm SD with six biological replicates.

\subsection{Effects of CMS on Enzyme Activities in Rapeseed during the Seedling Stage}

Plants have very efficient enzymatic antioxidant defense systems to protect plant cells from oxidative damage by scavenging of ROS which controls many processes including plant growth and development [19]. When supplied with different concentrations of CMS in the growth media, the activities of SOD, CAT and POD showed obvious changes (Figure 7). High concentrations of CMS 
$\left(0.20 \mathrm{~g} \mathrm{~L}^{-1}\right)$ resulted in a decrease of CAT and POD activities and increased SOD activity in shoot compared with the control condition. In the root, high concentrations of CMS inhibited the activity of POD. However, at low concentrations of CMS $\left(0.05 \mathrm{~g} \mathrm{~L}^{-1}\right)$, there were no differences for the activities of SOD, POD and CAT in both shoot and root compared with the full nutrient condition, except the activity of SOD in the shoot, which showed a significant increase (Figure 7). As the concentration of CMS was increased, the contents of MDA in shoot and root were all increased and reached a significant difference at high concentrations of CMS in the environment. The results suggest that a high concentration of CMS is not conducive to the growth and development of rapeseed, which may cause serious damage to the plants.

A

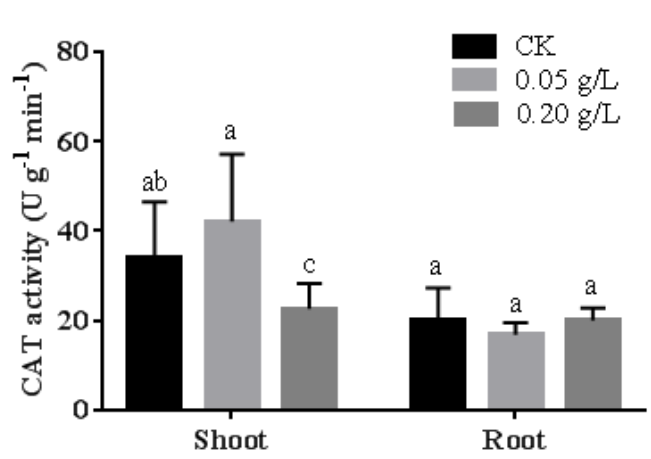

B

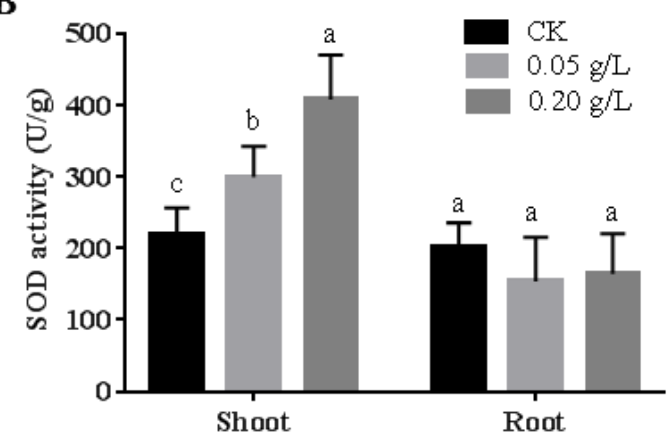

C

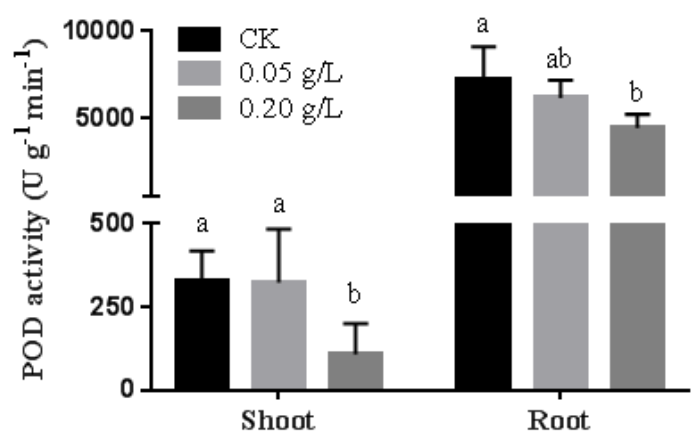

D

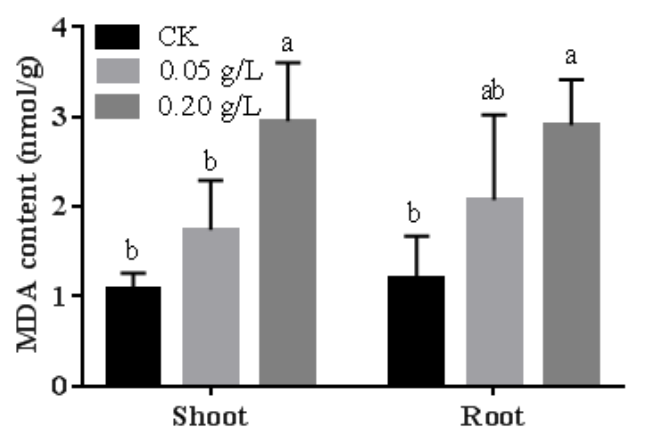

Figure 7. The enzyme activities and malondialdehyde (MDA) content in shoot and root of Brassica napus under different CMS treatments. CK is a full-strength Hoagland's solution. Two concentrations ( 0.05 and $0.20 \mathrm{~g} \mathrm{~L}^{-1}$ ) of CMS were added to the Hoagland's solution. (A) The CAT activity; (B) The SOD activity; (C) The POD activity; (D) The MDA content. Different letters indicate the significant differences at $p<0.05$ by Duncan's test. Data are means \pm SD with four biological replicates.

\subsection{Effects of Exogenous Application of CMS on Rapeseed Growth at the Mature Stage}

To further determine the effects of CMS on the growth and seed yield of oilseed rape at the mature stage, 10 treatments including non-fertilization (T1), normal nutrient supply (T5) and eight treatments with different concentrations of CMS were applied to the field at different rapeseed growth season (Table 2). Clearly, compared to T1, exogenous application of CMS and chemical fertilizers improved the growth performance of rapeseed (Figure 8; Table 3), but no differences were observed under low concentrations of CMS (T2 and T3). A significant increase was detected under the high application of CMS (T4) for seed yield and yield-related traits compared with T1 (Figure 8; Table 3). The seed yield, branch number, pod number, seed number per pod and plant height were significantly higher than that of non-fertilization treatment when applying CMS together with chemical fertilizers (T6-T10). Applying CMS together with chemical fertilizers showed no significant changes in plant height, seed weight, first primary branch height, branch number and seed number per pod compared with the 
normal chemical fertilization (T5) (Table 3). However, the above-ground biomass and seed yield was increased with the increase of CMS application rate and reached the maximum at T8 treatment (Figure 8). In terms of the application period, the effect was better at the seedling stage (T8) than that of other periods. Compared with the normal fertilization treatment (T5), the seed yield and above-ground biomass of T8 treatment were increased by about $20 \%$ (Figure 8 ). Moreover, exogenous CMS application at bolting and flowering stages had no effect on rapeseed growth and yield formation compared with normal chemical fertilizer application (Figure 8; Table 3).

A

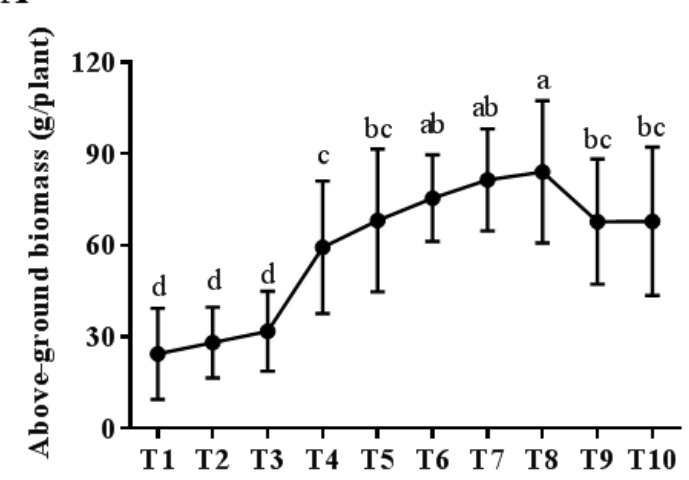

C

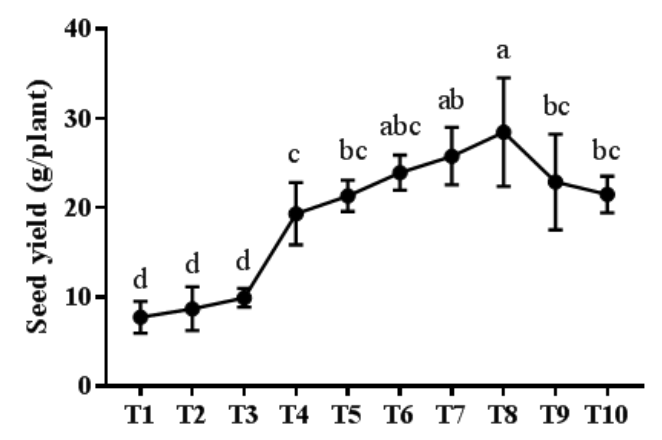

B

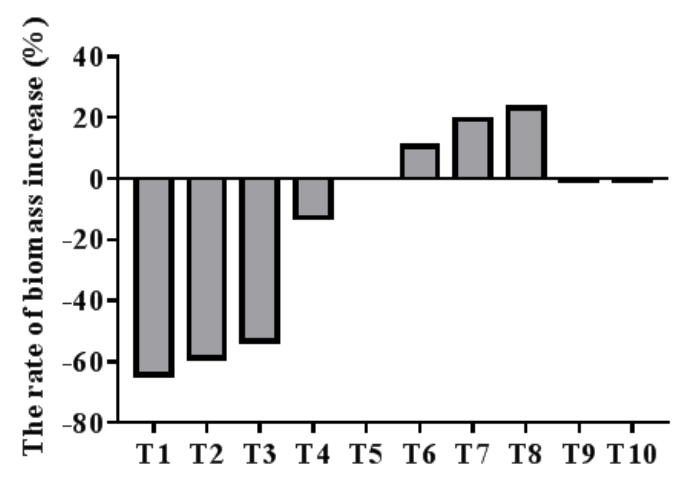

D

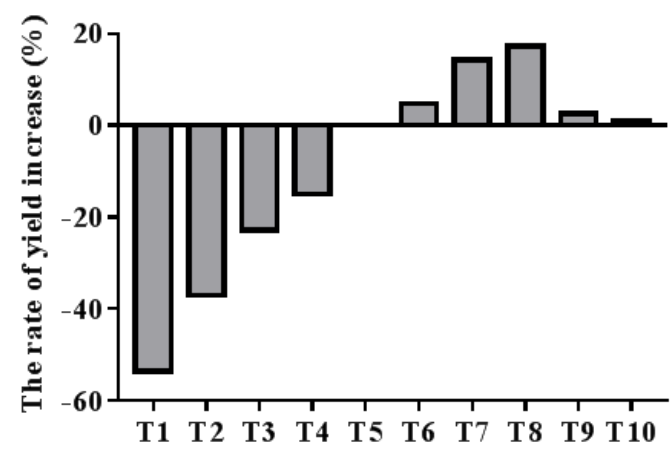

Figure 8. The above-ground biomass and seed yield of Brassica napus at the mature stage under different CMS treatments. Ten different treatments (T1-T10) were conducted in the field trials. No fertilizer was applied in T1 treatment. T2, T3, and T4 were treated with 50, 200, and $500 \mathrm{~g} \mathrm{~m}^{-2} \mathrm{CMS}$ before sowing without any chemical fertilizers, respectively. Normal chemical fertilization without any CMS were applied in T5. For T6 and T7 treatments, chemical fertilizers together with 50 and $200 \mathrm{~g} \mathrm{~m}^{-2} \mathrm{CMS}$ were applied before sowing, respectively. For T8, T9, and T10 treatments, normal chemical fertilization was applied, while $200 \mathrm{~g} \mathrm{~m}^{-2} \mathrm{CMS}$ were applied at seedling, bolting, and flowering stages, respectively. (A) Above-ground biomass; (B) Seed yield; (C) The rate of biomass increase; (D) The rate of yield increase. Different letters indicate the significant differences at a $p<0.05$ by Duncan's test. Data are means \pm SD from 16 individuals.

\subsection{Effects of Exogenous Application of CMS on Rapeseed Nutrient Uptake at the Mature Stage}

To further check the effects of CMS on nutrient uptake and distribution of rapeseed at the mature stage, we measured $\mathrm{N}, \mathrm{P}$ and $\mathrm{K}$ concentrations in different parts of rapeseed plants under five (T1, T4, T5, T7 and T8) treatments, and calculated the nutrient accumulation in these parts. Generally, the concentrations of $\mathrm{N}$ and $\mathrm{P}$ were higher in seeds than in husk and other parts of the rapeseed plants as well as the nutrient accumulation. However, it showed the opposite trend for K concentration and content (Figure 9). Small changes were observed for the nutrient uptake in each part of the plants among all the five treatments tested. In seeds and husk, lower concentrations of $\mathrm{N}$ and P were detected under T8 treatment than T1 treatment, but no difference was observed for K concentration (Figure 9). 
Table 3. Yield-related traits of Brassica napus under different treatments in the field trial.

\begin{tabular}{ccccccc}
\hline Treatments & $\begin{array}{c}\text { Seed } \\
\text { Weight }(\mathbf{g})\end{array}$ & $\begin{array}{c}\text { Plant Height } \\
(\mathbf{c m})\end{array}$ & $\begin{array}{c}\text { First Primary Branch } \\
\text { Height }(\mathbf{c m})\end{array}$ & $\begin{array}{c}\text { Branch } \\
\text { Number }\end{array}$ & Pod Number & $\begin{array}{c}\text { Seed Number } \\
\text { Per Pod }\end{array}$ \\
\hline T1 & $2.00 \pm 0.12 \mathrm{a}$ & $134.19 \pm 20.86 \mathrm{~d}$ & $59.69 \pm 18.47 \mathrm{a}$ & $2.3 \pm 1.5 \mathrm{c}$ & $116.9 \pm 19.2 \mathrm{~d}$ & $19.9 \pm 1.1 \mathrm{~cd}$ \\
T2 & $1.95 \pm 0.05 \mathrm{a}$ & $144.25 \pm 13.82 \mathrm{~cd}$ & $63.75 \pm 12.11 \mathrm{a}$ & $3.8 \pm 1.0 \mathrm{~b}$ & $147.9 \pm 16.4 \mathrm{~cd}$ & $17.5 \pm 1.1 \mathrm{~d}$ \\
T3 & $1.95 \pm 0.25 \mathrm{a}$ & $143.31 \pm 12.97 \mathrm{~cd}$ & $69.56 \pm 9.67 \mathrm{a}$ & $3.9 \pm 1.2 \mathrm{~b}$ & $126.3 \pm 14 \mathrm{~d}$ & $17.4 \pm 1.4 \mathrm{~d}$ \\
T4 & $1.93 \pm 0.27 \mathrm{a}$ & $156.31 \pm 29.38 \mathrm{bc}$ & $63.06 \pm 12.65 \mathrm{a}$ & $5.3 \pm 1.9 \mathrm{a}$ & $190.0 \pm 47.7 \mathrm{bc}$ & $22.2 \pm 1.3 \mathrm{bc}$ \\
T5 & $2.07 \pm 0.14 \mathrm{a}$ & $170.38 \pm 16.22 \mathrm{ab}$ & $70.13 \pm 11.70 \mathrm{a}$ & $5.4 \pm 1.4 \mathrm{a}$ & $222.3 \pm 19.5 \mathrm{bc}$ & $25.0 \pm 0.5 \mathrm{ab}$ \\
T6 & $1.98 \pm 0.02 \mathrm{a}$ & $171.75 \pm 13.62 \mathrm{a}$ & $63.56 \pm 18.76 \mathrm{a}$ & $6.0 \pm 1.6 \mathrm{a}$ & $281.8 \pm 25.8 \mathrm{ab}$ & $25.8 \pm 0.5 \mathrm{a}$ \\
T7 & $2.01 \pm 0.03 \mathrm{a}$ & $173.88 \pm 16.05 \mathrm{a}$ & $61.38 \pm 14.60 \mathrm{a}$ & $6.4 \pm 1.2 \mathrm{a}$ & $329.6 \pm 28.9 \mathrm{a}$ & $22.2 \pm 0.8 \mathrm{bc}$ \\
T8 & $1.99 \pm 0.26 \mathrm{a}$ & $173.88 \pm 8.02 \mathrm{a}$ & $63.69 \pm 12.43 \mathrm{a}$ & $6.3 \pm 1.7 \mathrm{a}$ & $340.1 \pm 30.3 \mathrm{a}$ & $24.4 \pm 0.9 \mathrm{ab}$ \\
T9 & $2.04 \pm 0.18 \mathrm{a}$ & $169.00 \pm 20.54 \mathrm{ab}$ & $70.25 \pm 16.10 \mathrm{a}$ & $5.7 \pm 1.4 \mathrm{a}$ & $279.0 \pm 34.8 \mathrm{ab}$ & $23.8 \pm 0.6 \mathrm{ab}$ \\
T10 & $1.94 \pm 0.05 \mathrm{a}$ & $162.81 \pm 32.95 \mathrm{ab}$ & $68.38 \pm 13.59 \mathrm{a}$ & $5.4 \pm 1.5 \mathrm{a}$ & $259.0 \pm 28.6 \mathrm{~b}$ & $24.4 \pm 0.3 \mathrm{ab}$ \\
\hline
\end{tabular}

Different letters (a, b, c, d) within a column represent significant differences at $p<0.05$.

A

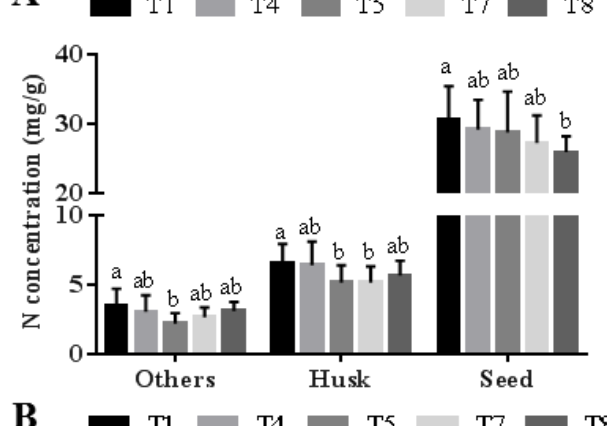

B $\square \mathrm{T} 1 \square \mathrm{T} 4 \square \mathrm{T} 4 \square \mathrm{T} 7 \square \mathrm{T} 8$
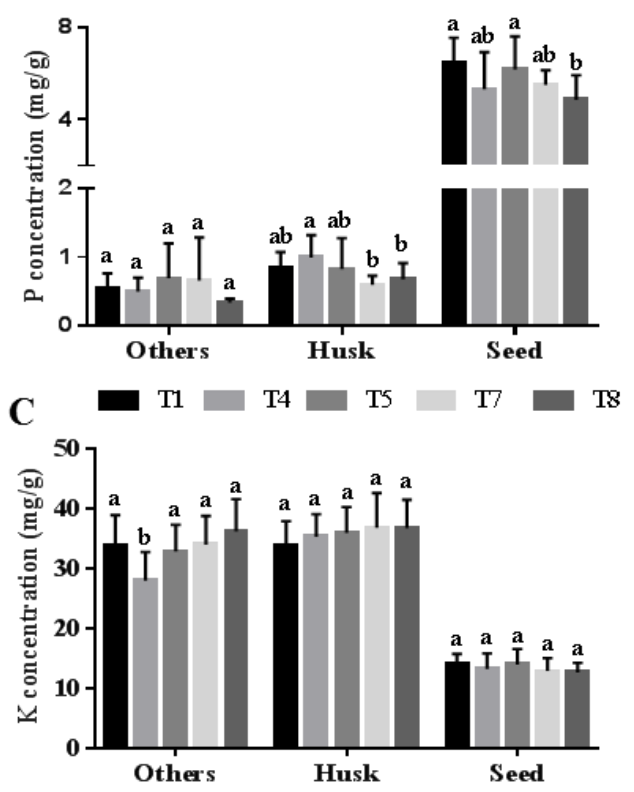
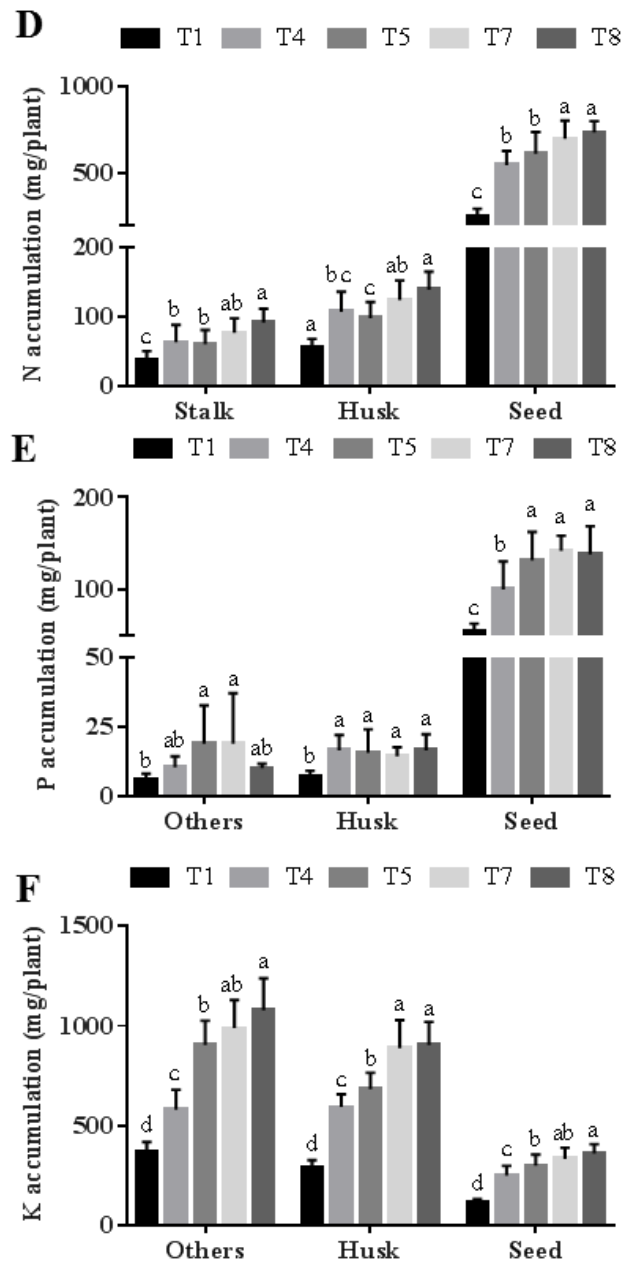

Figure 9. Mineral concentration in three parts of Brassica napus at the mature stage under different treatments. Ten different treatments were conducted in the field trial. Among them, four treatments were selected to investigate the nutrient concentrations. No fertilizer was applied in T1 treatment. T4 was treated with $500 \mathrm{~g} \mathrm{~m}^{-2} \mathrm{CMS}$ before sowing without any chemical fertilizers. Normal chemical fertilization without any CMS were applied in T5. For T7 treatment, chemical fertilizers together with $200 \mathrm{~g} \mathrm{~m}^{-2} \mathrm{CMS}$ were applied before sowing. For T8 treatment, normal chemical fertilization was applied, while $200 \mathrm{~g} \mathrm{~m}^{-2}$ CMS were applied at seedling stage. (A) N concentration; (B) P concentration; (C) $\mathrm{K}$ concentration; (D) N accumulation; (E) P accumulation; (F) K accumulation. Different letters indicate the significant differences at a $p<0.05$ by Duncan's test. Data are means \pm SD from 16 individuals. 
3.8. Effects of Exogenous Application of CMS on Seed Oil Content and Quality of Oilseed Rape

To further detect the effect of CMS on oil content and quality of rapeseed seeds, we measured the contents of oil, protein, glucosinolate, erucic acid and five other unsaturated fatty acids. Among all the treatments, the lowest contents of glucosinolate, erucic acid and oil were detected in T1 treatment and highest concentrations of glucosinolate and erucic acid were observed in T8 treatment (Table 4). T6 treatment significantly increased oil content but obviously decreased the protein content in comparison to $\mathrm{T} 1$ (Table 4). The linoleic acid in T1 treatment was the highest among all the treatments and significantly higher than that in T2, T3, T6, T7, T9 and T10 treatments (Table 4). Exogenous application of CMS on the basis of chemical fertilizers did not affect seed quality and oil content. 
Table 4. The oil content and seed quality of Brassica napus under different treatments.

\begin{tabular}{|c|c|c|c|c|c|c|c|c|c|}
\hline Treatments & $\begin{array}{c}\text { Oil Content } \\
(\%)\end{array}$ & Protein $(\%)$ & $\begin{array}{c}\text { Glucosinolate } \\
(\%)\end{array}$ & $\begin{array}{c}\text { Erucic Acid } \\
(\%)\end{array}$ & $\begin{array}{c}\text { Linolenic } \\
\text { Acid (\%) }\end{array}$ & $\begin{array}{c}\text { Linoleic Acid } \\
(\%)\end{array}$ & $\begin{array}{c}\text { Stearic Acid } \\
(\%)\end{array}$ & $\begin{array}{l}\text { Oleic Acid } \\
(\%)\end{array}$ & $\begin{array}{c}\text { Palmitic Acid } \\
(\%)\end{array}$ \\
\hline $\mathrm{T} 1$ & $44.3 \pm 1.9 \mathrm{~b}$ & $23.8 \pm 1.6 \mathrm{a}$ & $32.5 \pm 3.1 b$ & $2.1 \pm 0.7 b$ & $10.6 \pm 0.6 \mathrm{a}$ & $19.9 \pm 1.6 \mathrm{a}$ & $1.5 \pm 0.2 \mathrm{ab}$ & $60.8 \pm 2.3 \mathrm{ab}$ & $4.2 \pm 0.1 \mathrm{a}$ \\
\hline $\mathrm{T} 2$ & $48.5 \pm 0.6 \mathrm{ab}$ & $20.7 \pm 0.3 b c$ & $36.7 \pm 2.4 \mathrm{ab}$ & $2.7 \pm 1.3 b$ & $10.6 \pm 0.8 \mathrm{a}$ & $15.3 \pm 0.8 b$ & $1.1 \pm 0.1 \mathrm{~b}$ & $65.9 \pm 2.1 \mathrm{a}$ & $3.7 \pm 0.2 b$ \\
\hline $\mathrm{T} 3$ & $48.2 \pm 2.4 \mathrm{ab}$ & $20.8 \pm 1.7 \mathrm{bc}$ & $35.7 \pm 3.1 \mathrm{ab}$ & $2.2 \pm 1.2 \mathrm{~b}$ & $10.3 \pm 0.6 \mathrm{a}$ & $15.6 \pm 2.9 \mathrm{~b}$ & $1.3 \pm 0.4 \mathrm{ab}$ & $65.3 \pm 2.8 \mathrm{a}$ & $3.8 \pm 0.4 \mathrm{ab}$ \\
\hline $\mathrm{T} 4$ & $45.5 \pm 3.4 \mathrm{ab}$ & $22.2 \pm 2.4 \mathrm{ab}$ & $36.1 \pm 2.2 \mathrm{ab}$ & $1.1 \pm 0.6 \mathrm{~b}$ & $10.1 \pm 1.1 \mathrm{a}$ & $17.8 \pm 0.8 \mathrm{ab}$ & $1.6 \pm 0.2 \mathrm{a}$ & $62.5 \pm 1.9 \mathrm{ab}$ & $4.1 \pm 0.1 \mathrm{a}$ \\
\hline T5 & $47.3 \pm 2.8 \mathrm{ab}$ & $19.5 \pm 2.0 \mathrm{bc}$ & $37.1 \pm 5.4 \mathrm{ab}$ & $2.3 \pm 2.1 b$ & $9.7 \pm 0.8 \mathrm{a}$ & $16.4 \pm 1.6 \mathrm{ab}$ & $1.6 \pm 0.3 \mathrm{a}$ & $64.7 \pm 2.7 \mathrm{a}$ & $4.1 \pm 0.3 \mathrm{ab}$ \\
\hline T6 & $49.8 \pm 2.4 \mathrm{a}$ & $18.7 \pm 1.1 \mathrm{c}$ & $36.5 \pm 1.2 \mathrm{ab}$ & $3.5 \pm 2.1 b$ & $9.6 \pm 0.7 \mathrm{a}$ & $14.8 \pm 2.5 b$ & $1.2 \pm 0.1 \mathrm{ab}$ & $66.4 \pm 1.5 \mathrm{a}$ & $3.7 \pm 0.4 \mathrm{ab}$ \\
\hline $\mathrm{T} 7$ & $47.4 \pm 3.9 \mathrm{ab}$ & $20.2 \pm 2.1 \mathrm{bc}$ & $34.2 \pm 2.2 \mathrm{ab}$ & $4.7 \pm 5.1 \mathrm{~b}$ & $9.8 \pm 0.7 \mathrm{a}$ & $15.0 \pm 2.0 \mathrm{~b}$ & $1.3 \pm 0.3 \mathrm{ab}$ & $62.4 \pm 7.0 \mathrm{ab}$ & $3.9 \pm 0.4 \mathrm{ab}$ \\
\hline $\mathrm{T} 8$ & $49.0 \pm 2.1 \mathrm{ab}$ & $20.1 \pm 1.6 b c$ & $40.3 \pm 8.0 \mathrm{a}$ & $9.2 \pm 4.4 \mathrm{a}$ & $9.7 \pm 0.6 \mathrm{a}$ & $16.2 \pm 3.5 \mathrm{ab}$ & $1.4 \pm 0.3 \mathrm{ab}$ & $57.1 \pm 8.5 \mathrm{~b}$ & $4.0 \pm 0.3 \mathrm{ab}$ \\
\hline T9 & $48.2 \pm 2.8 \mathrm{ab}$ & $20.0 \pm 1.2 b c$ & $33.5 \pm 0.3 \mathrm{ab}$ & $2.7 \pm 0.7 \mathrm{~b}$ & $9.7 \pm 0.8 \mathrm{a}$ & $16.0 \pm 2.8 \mathrm{~b}$ & $1.2 \pm 0.3 \mathrm{ab}$ & $66.6 \pm 1.8 \mathrm{a}$ & $3.9 \pm 0.1 \mathrm{ab}$ \\
\hline $\mathrm{T} 10$ & $48.6 \pm 4.3 \mathrm{ab}$ & $20.2 \pm 2.3 b c$ & $36.0 \pm 5.6 \mathrm{ab}$ & $2.8 \pm 1.5 \mathrm{~b}$ & $10.1 \pm 0.9 \mathrm{a}$ & $15.7 \pm 3.6 b$ & $1.1 \pm 0.1 \mathrm{~b}$ & $65.2 \pm 3.2 \mathrm{a}$ & $4.0 \pm 0.3 \mathrm{ab}$ \\
\hline
\end{tabular}

Different letters $(\mathrm{a}, \mathrm{b}, \mathrm{c}, \mathrm{d})$ within a column represent significant differences at $p<0.05$. 


\subsection{Effects of CMS on Soil Fertility}

After exogenous application of CMS, we sampled the soil and measured the contents of organic matter, total N, Olsen-P and available $\mathrm{K}$ in it. Among the 10 treatments, the highest content of organic matter $\left(19.9 \mathrm{~g} \mathrm{~kg}^{-1}\right)$ was observed in T7, while the lowest $\left(14.1 \mathrm{~g} \mathrm{~kg}^{-1}\right)$ was observed in T1 (Table 5). The content of total $\mathrm{N}$ in T7 was $1.4 \mathrm{~g} \mathrm{~kg}^{-1}$, the highest among all the treatments, T1 showed the lowest value $\left(1.2 \mathrm{~g} \mathrm{~kg}^{-1}\right)$. Similar results were observed for the content of available P. In terms of $\mathrm{K}$ content, the highest value was detected in T4 among all the treatments, about $290.2 \mathrm{mg} \mathrm{kg}^{-1}$, which was significantly higher than any other treatments; T5 treatment showed the lowest available $\mathrm{K}\left(175.5 \mathrm{mg} \mathrm{kg}^{-1}\right)$.

Table 5. The contents of organic matter and mineral nutrients in soils under different treatments.

\begin{tabular}{ccccc}
\hline Treatments & $\begin{array}{c}\text { Organic Matter } \\
\mathbf{( g / \mathbf { k g } )}\end{array}$ & Total N (g/kg) & Olsen-P (mg/kg) & $\begin{array}{c}\text { Available K } \\
\mathbf{( m g / k g )}\end{array}$ \\
\hline T1 & $14.1 \pm 5.1$ & $1.2 \pm 0 \mathrm{~b}$ & $11.1 \pm 0.6$ & $194.1 \pm 21.5 \mathrm{bc}$ \\
T2 & $16.2 \pm 2.4$ & $1.2 \pm 0.1 \mathrm{ab}$ & $11.6 \pm 2.7$ & $199.0 \pm 11.7 \mathrm{bc}$ \\
T3 & $18.4 \pm 5.1$ & $1.3 \pm 0.1 \mathrm{ab}$ & $12.2 \pm 2.9$ & $228.4 \pm 36.1 \mathrm{~b}$ \\
T4 & $16.8 \pm 2.5$ & $1.3 \pm 0.1 \mathrm{ab}$ & $12.6 \pm 4.1$ & $290.2 \pm 50.6 \mathrm{a}$ \\
T5 & $14.6 \pm 1.5$ & $1.2 \pm 0.1 \mathrm{ab}$ & $14.1 \pm 3.8$ & $175.5 \pm 19.3 \mathrm{c}$ \\
T6 & $18.3 \pm 2.9$ & $1.3 \pm 0.1 \mathrm{ab}$ & $13.6 \pm 3.4$ & $191.2 \pm 24.0 \mathrm{bc}$ \\
T7 & $19.9 \pm 3.7$ & $1.4 \pm 0.2 \mathrm{a}$ & $14.3 \pm 2.8$ & $234.3 \pm 33.9 \mathrm{~b}$ \\
T8 & $17.2 \pm 4.5$ & $1.3 \pm 0.2 \mathrm{ab}$ & $12.7 \pm 3.7$ & $214.7 \pm 22.5 \mathrm{bc}$ \\
T9 & $16.0 \pm 2.2$ & $1.2 \pm 0.1 \mathrm{ab}$ & $12.2 \pm 6.2$ & $216.7 \pm 9.3 \mathrm{bc}$ \\
T10 & $16.1 \pm 2.1$ & $1.3 \pm 0.1 \mathrm{ab}$ & $12.3 \pm 4.9$ & $233.3 \pm 22.4 \mathrm{~b}$ \\
\hline
\end{tabular}

Different letters (a, b, c, d) within a column represent significant differences at $p<0.05$.

\section{Discussion}

Organic fertilizer contains large amounts of inorganic and trace elements that can be directly absorbed by crops. It can also serve as the source of nutrients, such as amino acids, amides and phospholipids. In addition, humic acid, cellulose and other substances in organic fertilizer can improve nutrient utilization. Besides its nutritional role, organic fertilizer can improve the physical and chemical properties of soil, and promote microbial activities. It has been reported that the application of organic fertilizers could increase plant yield and crop nutrient utilization [34,35]. For example, cover cropping with organic fertilizer can significantly increase rapeseed yields and reduce fertilizer application rates in B. napus without compromising yields [34]. Thus, organic fertilizer is gaining importance in agriculture $[22,34,35]$. Food industries such as distilleries, sugar and yeast production generate large volumes of high strength wastewater that is of serious environmental concern. Molasses wastewater is characterized by extremely high COD and BOD, apart from low $\mathrm{pH}$, strong odor and dark brown color [36]. However, CMS contains large amounts of mineral elements and organic matter which may be useful for agricultural production [6,7]. Despite the drawbacks of CMS, there are numerous reports which showed the safe application of CMS as an organic fertilizer without any harmful effects on the environments $[6,9,11]$. Thus, it is of significance to investigate the effects of exogenous application of CMS on the growth and development of rapeseed.

The phytohormones, including abscisic acid, gibberellin, ethylene and salicylic acid, can influence germination. Besides these phytohormones, a number of diverse germination stimulants are known to be involved in germination stimulation [37]. For example, some nitrogen-containing compounds including nitric oxide $(\mathrm{NO})$, nitrite $\left(\mathrm{NO}_{2}{ }^{-}\right)$and nitrate $\left(\mathrm{NO}_{3}{ }^{-}\right)$can reduce seed dormancy [38]. While these processes crosstalk with each other to improve dormancy release and seed germination [39]. Soaking plant seeds with an appropriate concentration of salicylic acid can improve the germination rate [40]. However, our experiment showed that the application of CMS had no significant effects on the seed germination rate of $B$. napus, but low concentrations of CMS could promote root elongation for the young seedlings (Figure 1). These results indicated that CMS had a positive regulatory effect on root growth at the very early stage of plants, which may contribute to the seedling growth. 
In the present study, exogenous addition of $0.05 \mathrm{~g} \mathrm{~L}^{-1} \mathrm{CMS}$ to the normal nutrient solution promoted the growth and development of rapeseed seedlings, whereas $0.20 \mathrm{~g} \mathrm{~L}^{-1} \mathrm{CMS}$ in the nutrient solution inhibited the growth (Figure 2), indicating that the dosage is vitally important. Furthermore, we found that the low concentration of CMS promoted the development of the root system, root vigor and nutrient use index at the seedling stage (Figure 3; Figure 6). ROS can be produced continuously as byproducts of various metabolic pathways. It can damage plant cells, and also acts as a signaling molecule [18]. In this research, we investigated the activities of SOD, CAT and POD, all of which work as ROS detoxifying proteins. The results showed that the activity of SOD was increased significantly in the shoot with the increase of CMS concentration, but there was no significant difference in root under three treatments. In terms of CAT and POD, there was no difference among all the treatments (Figure 7). MDA is an important indicator of ROS production. The content of MDA in plants could be used to reflect the degree of lipid peroxidation and the extent of plant damage $[19,20]$. Therefore, we further examined MDA contents at the seedling stage under three treatments. The results showed that MDA contents were higher under $0.20 \mathrm{~g} \mathrm{~L}^{-1} \mathrm{CMS}$ condition compared to control condition in shoot and root, but no difference was observed between $0.05 \mathrm{~g} \mathrm{~L}^{-1} \mathrm{CMS}$ and normal nutrient supply (Figure 7D), indicating increase of oxidative damage under high amount of CMS application but no effects under low concentration. In addition, root development was significantly induced by low concentrations of CMS, but inhibited largely by high concentrations of CMS with the symptom of necrosis (Figure 3), but the root vigor was significantly increased with the increase of CMS concentrations (Figure 2). Taken together, these results suggested that the application of low concentrations of CMS could promote shoot and root growth, and increase root vigor and nutrient use index, but have opposite results under high concentrations of CMS.

After applying organic fertilizer to the soil, CMS can effectively improve the physical and chemical properties, biological characteristics and soil fertility [22,34]. The application of organic fertilizers can increase crop yield and $\mathrm{N}$ use efficiency [35]. To further test the effects of CMS on the seed yield and quality of rapeseed, we conducted the field trials with 10 treatments. Our results showed that fertilization significantly increased seed yields of rapeseed as well as the above-ground biomass (Figure 8). Exogenous application of CMS at the seedling stage on the basis of chemical fertilization improved the growth and yield of up to $20 \%$ compared to chemical fertilization only. However, the promotion effects were not as clear when applying the same amount of CMS at other growth stages including bolting and flowering stages, indicating that the effects of CMS fertilizer were significantly affected by the application period. Molasses is rich in mineral elements and is often used primarily as a source of $\mathrm{K}$, due to containing high concentrations. Moreover, it has other significant advantages such as increasing organic matter in the soil and microbial activity associated with nitrification $[9,10]$. In this study, we further examined the contents of organic matter, N, P and K in soils after application of CMS. Higher contents of organic matter were observed after exogenous application of CMS than that under non-fertilization or chemical fertilization only, but the differences were not significant among them (Table 5). In terms of K, it showed a significant increase by the application of high levels of CMS, which again confirmed the role of CMS as a source of $\mathrm{K}$ fertilizer.

\section{Conclusions}

Condensed molasses soluble (CMS) on the basis of chemical fertilization could significantly enhance the growth of rapeseed, which is an important oil crop worldwide, at both seedling and ripening stages, and eventually increases yield without affecting seed oil content and quality. With the application of the same amount of CMS at different growth periods, we found that the final yield was only increased in the case of applying CMS as base fertilizer or at the seedling stage. High concentrations of CMS might induce the production of ROS, which causes damage in plants, while low concentrations of CMS could promote the growth of oilseed rape by stimulating root growth and nutrient use efficiency. Therefore, CMS could be used as organic fertilizer in rapeseed production. 
Author Contributions: Conceptualization, G.D.; formal analysis, S.L. and X.Z.; investigation, S.L. and X.Z.; data curation, X.Y. and L.Z.; writing-original draft preparation, G.D. and X.Z.; writing-review and editing, L.S. and F.X.; supervision, G.D.; funding acquisition, G.D. All authors have read and agreed to the published version of the manuscript.

Funding: This research was funded by grants from the National Key Research and Development Program of China (grant number 2018YFD0200900), the National Natural Science Foundation of China (grant number 31672215) and the Fundamental Research Funds for the Central Universities of China (grant number 2662019PY013).

Conflicts of Interest: The authors declare no conflict of interest. The funders had no role in the design of the study; in the collection, analyses or interpretation of data; in the writing of the manuscript, or in the decision to publish the results.

\section{References}

1. Liang, L.; Zhang, Y.P.; Zhang, L.; Zhu, M.J.; Liang, S.Z.; Huang, Y.N. Study of sugarcane pieces as yeast supports for ethanol production from sugarcane juice and molasses. J. Ind. Microbiol. Biot. 2008, 35, 1605-1613. [CrossRef]

2. Babu, N.K.; Satyanarayana, B.; Balakrishnan, K.; Rao, T.R.; Rao, G.S. Study of sugarcane pieces as yeast supports for ethanol production from sugarcane juice and molasses using newly isolated yeast from toddy sap. Mycobiology 2012, 40, 35-41. [CrossRef]

3. Satyawali, Y.; Balakrishnan, M. Wastewater treatment in molasses-based alcohol distilleries for COD and color removal: A review. J. Environ. Manag. 2008, 86, 481-497. [CrossRef] [PubMed]

4. Shan, L.; Liu, J.; Yu, Y.; Ambuchi, J.J.; Feng, Y. Characterization of persistent colors and decolorization of effluent from biologically treated cellulosic ethanol production wastewater. Environ. Sci. Pollut. Res. Int. 2016, 23, 10215-10222. [CrossRef] [PubMed]

5. Robles-Gonzalez, V.; Galindez-Mayer, J.; Rinderknecht-Seijas, N.; Poggi-Varaldo, H.M. Treatment of mezcal vinasses: A review. J. Biotechnol. 2012, 157, 524-546. [CrossRef] [PubMed]

6. Srivastava, P.C.; Singh, R.K.; Srivastava, P.; Shrivastava, M. Utilization of molasses based distillery effluent for fertigation of sugarcane. Biodegradation 2012, 23, 897-905. [CrossRef]

7. Joshi, H.C.; Pathak, H.; Chaudhary, A.; Kalra, N. Distillery effluent as a source of plant nutrients: Prospects and problems. Fert. News 1996, 41, 41-47.

8. Suganya, K.; Rajannan, G. Effect of onetime post-sown and pre-sown application of distillery spentwash on the growth and yield of maize crop. Bot. Res. Int. 2009, 2, 288-294.

9. Turner, P.E.; Meyer, J.H.; King, A.C. Field evaluation of concentrated molasses stillage as a nutrient source for sugarcane in Swaziland. Proc. S. Afr. Sug. Technol. Ass. 2002, 76, 61-70.

10. Wynne, A.T.; Meyer, J.H. An economic assessment of using molasses and condensed molasses soluble as a fertiliser in the south african sugar industry. Proc. S. Afr. Sug. Technol. Ass. 2002, 76, 71-78.

11. Ramana, S.; Biswas, A.K.; Singh, A.B.; Yadava, R.B.R. Relative efficacy of different distillery effluents on growth, nitrogen fixation and yield of groundnut. Bioresour. Technol. 2002, 81, 117-121. [CrossRef]

12. Kang, G.H.; Park, K.D.; Chung, K.Y.; Ha, H.S.; Kang, B.H.; Sohn, B.K.; Ha, H.S.; Heo, J.S.; Cho, J.S. Effects of condensed molasses soluble on chemical and biological properties of soil, and nitrogen mineralization. Korean J. Soil Sci. Fertil. 2004, 6158, 219-228.

13. Jiang, Z.P.; Li, Y.R.; Wei, G.P.; Liao, Q.; Su, T.M.; Meng, Y.C.; Zhang, H.Y.; Lu, C.Y. Effect of long-term vinasse application on physico-chemical properties of sugarcane field soils. Sugar Tech. 2012, 14, 412-417. [CrossRef]

14. Wang, Y.; Wei, M.; Bi, L.; Li, Y.; Wang, W.; Ye, Y. Effect of irrigating vinaase waste liquor on the activity of three kinds of enzymes and agronomic characters at seedling stage in sugarcane. Southwest China J. Agric. Sci. 2006, 19, 482-485. (In Chinese with English Abstract)

15. Wang, W.H.; Mo, Y.C.; Wang, Y.D.; Ye, Y.P.; Li, Y.R. Effects of molasses alcohol waste liquor on the growth and photosynthesis of sugarcane seedlings. Subtrop. Agric. Res. 2006, 2, 26-30. (In Chinese with English Abstract)

16. Mo, Y.C.; Ye, Y.P.; Shen, Z.Y.; Li, Y.R. Effect of vinasse on the photosynthetic and nitrogen metabolism physiological characteristics and cane yield of sugarcane. Soil Ferti. Sci. China 2009, 3, 62-66, (In Chinese with English Abstract).

17. Mittler, R.; Vanderauwera, S.; Suzuki, N.; Miller, G.; Tognetti, V.B.; Vandepoele, K.; Gollery, M.; Shulaev, V.; Van Breusegem, F. ROS signaling: The new wave? Trends Plant. Sci. 2011, 16, 300-309. [CrossRef] 
18. Choudhury, F.K.; Rivero, R.M.; Blumwald, E.; Mittler, R. Reactive oxygen species, abiotic stress and stress combination. Plant. J. 2017, 90, 856-867. [CrossRef]

19. Gill, S.S.; Tuteja, N. Reactive oxygen species and antioxidant machinery in abiotic stress tolerance in crop plants. Plant. Physiol. Biochem. 2010, 48, 909-930. [CrossRef]

20. Rehmani, M.S.; Chen, Q.Q.; Yan, J.L.; Cui, X.; Gao, S.D.; Niu, F.F.; Yang, L.; Yang, B.; Jiang, Y.Q. A novel stress-responsive BnaNAL1 transcriptional activator in oilseed rape positively modulates reactive oxygen species production and cell death. Environ. Exp. Bot. 2019, 163, 1-14. [CrossRef]

21. Wang, L.F.; Lu, X.P.; Yuan, H.Y.; Wang, B.; Shen, Q.R. Application of bio-organic fertilizer to control tomato fusarium wilting by manipulating soil microbial communities and development. Commu. Soil Sci. Plan. 2015, 46, 2311-2322. [CrossRef]

22. Qiu, X.K.; Wang, Y.H.; Hu, G.Q.; Wang, Q.H.; Zhang, X.W.; Dong, Y.J. Effect of different fertilization modes on physiological characteristics, yield and quality of chinese cabbage. J. Plant. Nutr. 2013, 36, 948-962. [CrossRef]

23. Li, Y.; Wang, X.; Zhang, H.; Wang, S.; Ye, X.; Shi, L.; Xu, F.S.; Ding, G.D. Molecular identification of the phosphate transporter family 1 (PHT1) genes and their expression profiles in response to phosphorus deprivation and other abiotic stresses in Brassica napus. PLoS ONE 2019, 14, e0220374. [CrossRef]

24. Ding, G.; Zhao, Z.; Liao, Y.; Hu, Y.; Shi, L.; Long, Y.; Xu, F. Quantitative trait loci for seed yield and yield-related traits, and their responses to reduced phosphorus supply in Brassica napus. Ann. Bot. 2012, 109, 747-759. [CrossRef] [PubMed]

25. Arnon, D.I. Copper enzymes in isolated chloroplasts. Polyphenoloxidase in beta vulgaris. Plant. Physiol. 1949, 24, 1-15. [CrossRef]

26. Vos, C.; Schat, H.; Waal, M.; Vooijs, R.; Ernst, W. Increased resistance to copper-induced damage of the root cell plasmalemma in copper tolerant Silene cucubalus. Plant. Physiol. 1991, 82, 523-528. [CrossRef]

27. Beauchamp, C.; Fridovich, I. Superoxide dismutase: Improved assays and an assay applicable to acrylamide gels. Anal. Biochem. 1971, 44, 276-287. [CrossRef]

28. Aebi, H. Catalase. In Methods of Enzymatic Analysis, 2nd ed.; Bergmeyer, H.-U., Ed.; Academic Press: Cambridge, MA, USA, 1974; Volume 2, pp. 673-684.

29. Cai, K.; Gao, D.; Luo, S.; Zeng, R.; Yang, J.; Zhu, X. Physiological and cytological mechanisms of silicon-induced resistance in rice against blast disease. Plant. Physiol. 2008, 134, 324-333. [CrossRef] [PubMed]

30. Hachiya, T.; Watanabe, C.K.; Boom, C.; Tholen, D.; Takahara, K.; Kawai-Yamada, Hirofumi, U.; Yukifumi, U.; Ichiro, T.; Ko, N. Ammonium-dependent respiratory increase is dependent on cytochrome pathway in Arabidopsis thaliana shoots. Plant. Cell Environ. 2010, 33, 1888-1897. [CrossRef]

31. Clemensson-Lindell, A. Triphenyltetrazolium chloride as an indicator of fine-root vitality and environmental stress in coniferous forest stands: Applications and limitations. Plant. Soil 1994, 159, 297-300. [CrossRef]

32. Thomas, R.L.; Sheard, R.W.; Moyer, J.R. Comparison of conventional and automated procedures for nitrogen, phosphorus, and potassium analysis of plant material using a single digestion. Agron. J. 1967, 59, 240-243. [CrossRef]

33. Sparks, D.L.; Page, A.; Helmke, P.; Loeppert, R.; Soltanpour, P.; Tabatabai, M.; Johnston, C.; Sumner, M. Methods of Soil Analysis. Part 3. Chemical Methods; Soil Science Society of America, Inc.: Madison, WI, USA, 1996.

34. Vaillancourt, M.; Chantigny, M.; Pageau, D.; Vanasse, A. Impact of a clover cover crop combined with organic or mineral fertilizer on yield and nitrogen uptake of canola. Can. J. Plant. Sci. 2018, 98, 332-334. [CrossRef]

35. Zhang, M.; Yao, Y.; Tian, Y.; Ceng, K.; Zhao, M.; Zhao, M.; Yin, B. Increasing yield and N use efficiency with organic fertilizer in Chinese intensive rice cropping systems. Field Crop. Res. 2018, 227, 102-109. [CrossRef]

36. Tsioptsias, C.; Petridis, D.; Athanasakis, N.; Lemonidis, I.; Deligiannis, A.; Samaras, P. Post-treatment of molasses wastewater by electrocoagulation and process optimization through response surface analysis. J. Environ. Manag. 2015, 164, 104-113. [CrossRef] [PubMed]

37. Rajjou, L.; Duval, M.; Gallardo, K.; Catusse, J.; Bally, J.; Job, C.; Job, D. Seed germination and vigor. Annu. Rev. Plant. Biol. 2012, 63, 507-533. [CrossRef]

38. Signorelli, S.; Considine, M.J. Nitric oxide enables germination by a four-pronged attack on aba-induced seed dormancy. Front. Plant. Sci. 2018, 9, 296-300. [CrossRef] 
39. Arc, E.; Sechet, J.; Corbineau, F.; Rajjou, L.; Marion-Poll, A. ABA crosstalk with ethylene and nitric oxide in seed dormancy and germination. Front. Plant. Sci. 2013, 4, 63-82. [CrossRef]

40. Semida, W.M.; Rady, M.M. Pre-soaking in 24-epibrassinolide or salicylic acid improves seed germination, seedling growth, and anti-oxidant capacity in Phaseolus vulgaris L. grown under $\mathrm{NaCl}$ stress. J. Hortic. Sci. Biotech. 2014, 89, 338-344. [CrossRef] 